\title{
Adsorption of Phenol from Aqueous Solution Using Lantana camara, Forest Waste: Kinetics, Isotherm, and Thermodynamic Studies
}

\author{
C. R. Girish ${ }^{1}$ and V. Ramachandra Murty ${ }^{2}$ \\ ${ }^{1}$ Department of Chemical Engineering, Manipal Institute of Technology, Manipal 576104, India \\ ${ }^{2}$ Department of Biotechnology, Manipal Institute of Technology, Manipal 576104, India \\ Correspondence should be addressed to C. R. Girish; girishcr1@rediffmail.com
}

Received 7 June 2014; Revised 10 August 2014; Accepted 18 August 2014; Published 29 October 2014

Academic Editor: Abdul Majeed Seayad

Copyright (C) 2014 C. R. Girish and V. Ramachandra Murty. This is an open access article distributed under the Creative Commons Attribution License, which permits unrestricted use, distribution, and reproduction in any medium, provided the original work is properly cited.

\begin{abstract}
The present work investigates the potential of Lantana camara, a forest waste, as an adsorbent for the phenol reduction in wastewater. Batch studies were conducted with adsorbent treated with $\mathrm{HCl}$ and $\mathrm{KOH}$ to determine the influence of various experimental parameters such as $\mathrm{pH}$, contact time, adsorbent dosage, and phenol concentration. The experimental conditions were optimized for the removal of phenol from wastewater. Equilibrium isotherms for the adsorption of phenol were analyzed by Freundlich, Langmuir, Temkin, and Dubinin-Radushkevich isotherm models. Thermodynamic parameters like the Gibbs free energy $\left(\Delta G^{\circ}\right)$, enthalpy $\left(\Delta H^{\circ}\right)$, and entropy $\left(\Delta S^{\circ}\right)$ were also determined and they showed that the adsorption process was feasible, spontaneous, and exothermic in the temperature range of 298-328 K. The kinetic data were fitted with pseudo-second-order model. The equilibrium data that followed Langmuir model with the monolayer adsorption capacity was found to be $112.5 \mathrm{mg} / \mathrm{g}$ and $91.07 \mathrm{mg} / \mathrm{g}$ for adsorbent treated with $\mathrm{HCl}$ and $\mathrm{KOH}$, respectively, for the concentration of phenol ranging from 25 to $250 \mathrm{mg} / \mathrm{L}$. This indicates that the Lantana camara was a promising adsorbent for the removal of phenol from aqueous solutions.
\end{abstract}

\section{Introduction}

Phenol is one of the crucial pollutants released from the wastewater originating from the chemical industries like pulp and paper, gas and coke manufacturing, tanning, textile, plastics, rubber, pharmaceutical industries, ferrous industries and petroleum refinery and its substantial concentration in wastewater is listed in Table $1[1,2]$.

Phenol causes adverse effects on public health and environment. As per United States Environmental Protection Agency (USEPA) the allowable concentration of phenol in surface water should be less than $1.0 \mu \mathrm{g} / \mathrm{L}$ [3]. Phenolic compounds are very harmful even at very low concentrations due to their toxic and carcinogenic properties. They cause damage to the eyes and the tissue under the skin, inhalation, or ingestion, can damage the respiratory and gastrointestinal tracts, and can lead to genetic damage [4]. Phenol is designated as the 11th of the 126 priority pollutants by the United
States Environmental Protection Agency [5]. Therefore, it is an indispensable requirement to treat the phenol from industrial effluents before discharging into the water stream.

Various treatment methods such as biodegradation, biosorption, membrane separation, pervaporation, solvent extraction, distillation, and adsorption using activated carbon prepared from various precursors had been reviewed by Girish and Ramachandra Murty [6] to remove phenolic compounds from aqueous solution. Adsorption on activated carbon is the most widely used and the most effective adsorbent in treating phenolic wastewaters. It was elucidated that activated carbon can be formed from any carbonaceous solid precursor material. The desired physical and chemical properties that can be attained in the final activated carbon can be managed by the selection of the starting material. A wide range of diverse materials have been investigated as potential adsorbents for phenol removal in wastewater treatment. The prominent among them comprises silica gel 
TABLE 1: The concentration of phenol in wastewater released from various industries.

\begin{tabular}{lc}
\hline Industrial source & Phenol concentration, mg/L \\
\hline Petroleum refineries & $40-185$ \\
Petrochemical & $200-1220$ \\
Textile & $100-150$ \\
Leather & $4.4-5.5$ \\
Coke ovens & $600-3900$ \\
Coal conversion & $1700-7000$ \\
Ferrous industry & $5.6-9.1$ \\
Rubber industry & $3-10$ \\
Pulp and paper industry & 22 \\
Wood preserving industry & $50-953$ \\
Phenolic resin production & 1600 \\
Phenolic resin & $1270-1345$ \\
Fiberglass manufacturing & $40-2564$ \\
Paint manufacturing & 1.1 \\
\hline
\end{tabular}

$[7,8]$, activated alumina $[9,10]$, zeolites $[4,11]$, and red mud $[12,13]$.

But the drawback associated with the above materials is high cost and being nonrenewable in nature, which is a major economic consideration. This has excited a growing research interest in the production of activated carbon from locally available agricultural materials, especially for application concerning wastewater treatment [14]. Girish and Murty [15] reviewed the various agricultural by-products found to be suitable precursors for production of activated carbon. Mohd Din et al. [16] described that the biomass obtained from these materials is cheaper, renewable, and abundantly available. So an attempt has been made to use agricultural waste materials as an adsorbent for reducing the pollutant in wastewater.

A vast number of agricultural materials have been used as adsorbents for the removal of phenolic compounds from wastewater. These include date stone [17], Tamarindus indica [18], vegetal cord [19], banana peel [20], palm seed coat [21], oil palm empty fruit bunch [22], date pit [23], black stone cherries [24], vetiver roots [25], sugarcane bagasse [26], and Luffa cylindrica [27]. All these materials provide an alternative to conventional sources, which are prospective raw materials for activated carbon production. Also, using these agricultural materials for adsorbent preparation brings the solution to the problem of handling wastes [16].

In the process of quest for new agricultural wastes as precursor for adsorbent, attempts have been made to produce adsorbent from dry stem of lantana trees by the chemical treatment process. Lantana camara is a poisonous weed that has been expanded in many regions of the world and it poses major threats to ecosystem [28]. The lantana stem was collected from the tropical moist deciduous forests, that is, eastern side of Western Ghats, Coorg region, Karnataka, India. In this study, the potential of chemically treated carbon from lantana barks was studied for the removal of phenol from aqueous solution.
A systematic study of the adsorption of phenol on chemically treated lantana material was reported. It also addresses the batch experiments conducted to study the effect of process variables such as $\mathrm{pH}$, adsorbent dosage, initial phenol concentrations, and temperature on adsorption. The optimum experimental conditions were determined and thermodynamic studies were carried out to determine the nature of the adsorption process. From the literature, it is understood that the adsorption of phenol can be by three possible mechanisms: the $\pi-\pi$ dispersion interaction, the hydrogen bonding formation, and the electron donor-acceptor complex mechanism [29-31]. Therefore, in order to understand the above mechanisms, different adsorption isotherms (Langmuir, Freundlich, Temkin, and Dubinin-Radushkevich isotherms) and kinetic models (pseudo-first, pseudo-second-order kinetics and intraparticle diffusion) were investigated to find out the most suitable models describing the experimental findings and the adsorbate-adsorbent interactions.

\section{Materials and Methods}

2.1. Materials. Phenol has a chemical formula $\mathrm{C}_{6} \mathrm{H}_{5} \mathrm{OH}$ with a molecular weight of $94 \mathrm{~g} / \mathrm{mol}$. Phenol of analytical grade (Merck India Ltd.) was used for the preparation of stock solution of concentration $1000 \mathrm{mg} / \mathrm{L}$. The experimental solutions of concentration varying from 25 to $250 \mathrm{mg} / \mathrm{L}$ were prepared by diluting the stock solution to accurate proportions.

The other chemicals potassium hydroxide (Merck India Ltd., AR grade), potassium nitrate (Merck India Ltd., AR grade), zinc chloride (Merck India Ltd., AR grade), hydrochloric acid (SD Fine Chemicals, India, AR grade), sulphuric acid (SD Fine Chemicals, India, AR grade), and orthophosphoric acid (SD Fine Chemicals, India, AR grade) were used for the chemical treatment of carbon.

2.2. Preparation of Chemically Treated Carbon. The material Lantana camara was washed with distilled water for several times to remove all the foreign matters. The materials were initially dried in sunlight for $48 \mathrm{~h}$, made into pieces, grounded to powder, and sieved to several particle sizes less than $0.075 \mathrm{~mm}$. The proximate analysis of the raw powder was conducted to determine the fixed carbon, volatile matter, moisture, and ash content and is shown in Table 2. In order to improve the surface properties of the raw powder, various chemicals such as $3 \mathrm{M} \mathrm{H}_{3} \mathrm{PO}_{4}, 3 \mathrm{M} \mathrm{H}_{2} \mathrm{SO}_{4}, 3 \mathrm{M} \mathrm{HCl}, 3 \mathrm{M}$ $\mathrm{ZnCl}_{2}, 3 \mathrm{M} \mathrm{KNO}_{3}$, and $3 \mathrm{M} \mathrm{KOH}$ in a 1:1 ratio were added. Initially the powder was thoroughly mixed with the chemical overnight and then the slurry formed was dried at $105^{\circ} \mathrm{C}$ for $6 \mathrm{~h}$ in an oven. Then sufficient water was added to the mixture to remove the excess chemicals [32]. The process of washing with water was repeated 3-4 times until $\mathrm{pH}$ comes to 7 [33]. Then the powder was dried and stored for further studies. Initially the average particle size, pore volume, specific surface area, and removal capacity of the various chemically treated carbons and untreated carbon were investigated. Based on the preliminary results, as shown in Table 2, only the best two adsorbents treated with $\mathrm{HCl}$ and $\mathrm{KOH}$ were used for further analysis. 
TABLE 2: The proximate analysis of the untreated carbon.

\begin{tabular}{lc}
\hline Parameter & Value (\%) \\
\hline Volatile matter & 46.66 \\
Moisture & 6.66 \\
Ash & 5.229 \\
Fixed carbon & 41.451 \\
\hline
\end{tabular}

2.3. Characterization of Activated Carbon. The various properties were determined by the standard procedures [34]. The moisture content of the raw powder was found by heating a known weight of the sample in an air oven maintained at $110^{\circ} \mathrm{C}$ for about $60 \mathrm{~min}$. Then the residue was ignited in a muffle furnace at $750^{\circ} \mathrm{C}$ for about $8 \mathrm{~h}$ and at $900^{\circ} \mathrm{C}$ for about $10 \mathrm{~min}$ to determine ash content and volatile matter, respectively. The average particle size was determined by particle size analyser (CILAS 1064, France). The surface area and total pore volume measurement of carbon were carried out using BET apparatus (Smart Instruments, India). The surface functional groups of carbon were estimated by Fourier transform infrared (FTIR) spectroscopy instrument (Shimadzu 8400S, Japan).

2.4. Adsorption Experiments. The influence of various experimental parameters such as $\mathrm{pH}$, adsorbent dosage, contact time, and temperature on the adsorption of phenol from aqueous solutions was optimised in a batch mode of studies. The $\mathrm{pH}$ of solution was maintained at 2.5 to 12 by adding $0.1 \mathrm{M} \mathrm{HCl}$ or $0.1 \mathrm{M} \mathrm{NaOH}$; the adsorbent dosages of both $\mathrm{HCl}$ and $\mathrm{KOH}$ treated carbon were varied from 0.25 to $3 \mathrm{~g}$ and the temperature varied from 298 to $328 \mathrm{~K}$. After optimising the experimental parameters, the equilibrium and kinetic and thermodynamic studies were conducted in $250 \mathrm{~mL}$ conical flasks containing $200 \mathrm{~mL}$ phenol solution of different initial concentrations of $25,50,100,150,200$, and $250 \mathrm{mg} / \mathrm{L}$ under the optimum conditions. The flasks were agitated in a temperature controlled shaker at $140 \mathrm{rpm}$ and $298 \mathrm{~K}$ for $7 \mathrm{~h}$ and $8 \mathrm{~h}$, respectively, for adsorbent treated with $\mathrm{HCl}$ and $\mathrm{KOH}$, respectively, until equilibrium was established. After reaching the equilibrium time, the samples were taken from the flasks and filtered and the residual phenol concentrations were analysed using double beam UV spectrophotometer (UV-1700, Shimadzu, Japan). The samples were analysed spectrophotometrically at a wavelength of $270 \mathrm{~nm}$ by the aid of technical calibration curve prepared prior to the analysis [16]. The thermodynamic study was carried out in $250 \mathrm{~mL}$ conical flasks containing $200 \mathrm{~mL}$ phenol solution of different initial concentrations of $25,50,100,150,200$, and $250 \mathrm{mg} / \mathrm{L}$ under the optimum conditions by varying temperature from 298 to $328 \mathrm{~K}$. All sets of experiments were performed in duplicate under the optimum conditions and the mean values are presented. The error obtained was between 2.0 and $4.5 \%$.

The amount of phenol adsorbed per gram of carbon $\left(q_{e}\right)$ was obtained using the following expression:

$$
q_{e}=\frac{V *\left(C_{0}-C_{e}\right)}{1000 M}
$$

where $q_{e}$ is the equilibrium adsorption capacity $(\mathrm{mg} / \mathrm{g}), V$ is the solution volume $(L), C_{0}(\mathrm{mg} / \mathrm{L})$ is the initial phenol concentration, $C_{e}(\mathrm{mg} / \mathrm{L})$ is the equilibrium phenol concentration, and $M$ is the weight of the carbon powder (g).

The percentage removal of the phenol is given by

$$
\% \text { Removal }=\frac{C_{0}-C_{e}}{C_{0}} * 100 .
$$

2.5. Batch Kinetic Studies. The kinetic studies were carried out similar to those of equilibrium studies. The aqueous samples were collected at regular intervals and the concentrations of phenol solutions were similarly measured.

\section{Results and Discussions}

3.1. Characterisation of the Adsorbent. The proximate analysis of the raw powder which was carried out is shown in Table 2 . The average particle size, pore volume, specific surface area, and removal capacity of the various carbons are shown in Table 3. Of the six adsorbent options, adsorbents treated with $\mathrm{HCl}$ and $\mathrm{KOH}$ were found to exhibit better results and were studied further. It was also inferred that the adsorption capacity of carbon is dependent on the porosity, specific surface area, and chemical composition.

The FTIR spectra of adsorbent treated with $\mathrm{HCl}$ before and after phenol adsorption are shown in Figure 1. FTIR spectrum of carbon before phenol adsorption shows peaks at $2923 \mathrm{~cm}^{-1}$ due to $\mathrm{O}-\mathrm{H}$ stretching in carboxylic group, the peak at $3620 \mathrm{~cm}^{-1}$ shows $\mathrm{OH}$ stretching of phenol group [35], the peak observed at $1203 \mathrm{~cm}^{-1}$ is $\mathrm{C}-\mathrm{O}$ group attributed to alcohol, the band at $2376 \mathrm{~cm}^{-1}$ indicates the presence of $\mathrm{C} \equiv \mathrm{C}$ of alkynes [36], and at $1558 \mathrm{~cm}^{-1}$ is ascribed to $\mathrm{C}=\mathrm{C}$ aromatic ring stretching vibration [16]. The peak at 879 and $810 \mathrm{~cm}^{-1}$ was ascribed to $\mathrm{C}-\mathrm{H}$ group of alkenes and at $1689 \mathrm{~cm}^{-1}$ due to $\mathrm{C}=\mathrm{O}$ stretch of carboxylic acid [37]. The changes in peak of the spectral analysis for the various functional groups which could be the possible sites for phenol adsorption are shown in Table 4.

The adsorbent treated with $\mathrm{KOH}$ showed the FTIR spectrum as given in Figure 2. The peak at $3610 \mathrm{~cm}^{-1}$ is attributed to $\mathrm{O}-\mathrm{H}$ stretching in phenol, the peak at $871 \mathrm{~cm}^{-1}$ is assigned to $\mathrm{C}-\mathrm{H}$ of aromatic ring, the peak at $1365 \mathrm{~cm}^{-1}$ indicates the $\mathrm{C}-\mathrm{O}$ bond of alcohol, and the band at 671 and $1010 \mathrm{~cm}^{-1}$ [38] is because of $\mathrm{O}-\mathrm{H}$ stretching and $\mathrm{C}-\mathrm{O}-\mathrm{C}$ stretching of benzene derivative, respectively. The band at $2923 \mathrm{~cm}^{-1}$ shows C-H stretching of aliphatic group [39] and $2329 \mathrm{~cm}^{-1}$ is because of $\mathrm{C} \equiv \mathrm{C}$ of alkynes, respectively [16]. The band obtained at $1743 \mathrm{~cm}^{-1}$ is because of stretching vibration of $\mathrm{C}=\mathrm{O}$ in carboxyl group [40]. Similarly the changes in peak of the spectral analysis for the various functional groups are indicated in Table 5, which could be the possible sites for phenol adsorption.

3.2. Effect of $p H$. Because of the amphoteric nature of a carbon surface, the adsorption properties are influenced by the $\mathrm{pH}$ value of the solution. Phenol is a weak acid with acid dissociation value (pKa) of 9.8 and it dissociates 
TABLE 3: The removal capacity, average particle size, pore volume, and the specific surface area for various carbons.

\begin{tabular}{lccccccc}
\hline & & \multicolumn{5}{c}{ Chemically treated carbons } \\
& Untreated & $\mathrm{H}_{3} \mathrm{PO}_{4}$ & $\mathrm{KNO}_{3}$ & $\mathrm{H}_{2} \mathrm{SO}_{4}$ & $\mathrm{ZnCl}_{2}$ & $\mathrm{HCl}$ & $\mathrm{KOH}^{2}$ \\
\hline Particle size, $\mu \mathrm{m}$ & 23.86 & 17.98 & 16.19 & 19.71 & 14.22 & 11.59 & 11.68 \\
Specific surface area, $\mathrm{m}^{2} / \mathrm{g}$ & 115.15 & 109.90 & 210.59 & 170.71 & 206.65 & 349.56 \\
Pore volume, $\mathrm{m}^{3} / \mathrm{g}$ & 0.1113 & 0.1305 & 0.1789 & 0.1716 & 0.1392 & 0.2780 & 0.2761 \\
\% Phenol removal & 68.9 & 72.6 & 82.3 & 84.1 & 76.2 & 94.4 \\
\hline
\end{tabular}

TABLE 4: The FTIR spectral analysis of adsorbent treated with $\mathrm{HCl}$.

\begin{tabular}{|c|c|c|c|c|}
\hline \multirow{2}{*}{ Peak } & \multicolumn{2}{|c|}{ Frequency $\left(\mathrm{cm}^{-1}\right)$} & \multirow{2}{*}{ Difference } & \multirow{2}{*}{ Assignment } \\
\hline & Before adsorption & After adsorption & & \\
\hline 1 & 3620 & 3610 & -10 & $\mathrm{O}-\mathrm{H}$ stretching in phenol \\
\hline 2 & 1203 & 1218 & -15 & $\mathrm{C}-\mathrm{O}$ group in alcohol \\
\hline 3 & 1689 & 1697 & +8 & $\mathrm{C}=\mathrm{O}$ stretch of carboxylic acid \\
\hline 4 & 1558 & 1566 & +8 & $\mathrm{C}=\mathrm{C}$ bond of aromatic ring \\
\hline
\end{tabular}

TABLE 5: The FTIR spectral analysis of adsorbent treated with KOH.

\begin{tabular}{|c|c|c|c|c|}
\hline \multirow{2}{*}{ Peak } & \multicolumn{2}{|c|}{ Frequency $\left(\mathrm{cm}^{-1}\right)$} & \multirow{2}{*}{ Difference } & \multirow{2}{*}{ Assignment } \\
\hline & Before adsorption & After adsorption & & \\
\hline 1 & 3610 & 3633 & +23 & $\mathrm{O}-\mathrm{H}$ stretching in phenol \\
\hline 2 & 1365 & 1362 & -3 & $\mathrm{C}-\mathrm{O}$ ring of alcohol \\
\hline 3 & 2923 & 2920 & -3 & $\mathrm{C}-\mathrm{H}$ stretching of alkane group \\
\hline 4 & 1743 & 1712 & -31 & $\mathrm{C}=\mathrm{O}$ in carboxylic group \\
\hline
\end{tabular}

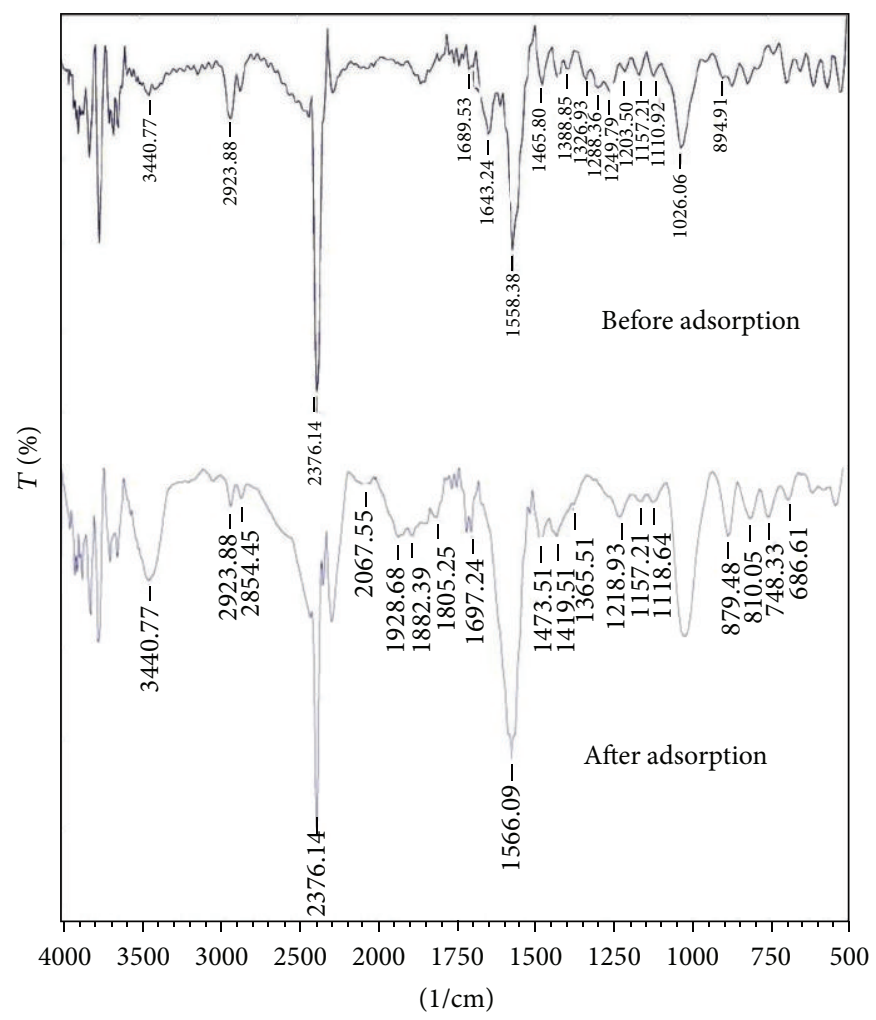

FIGURE 1: The FTIR spectra of adsorbent treated with $\mathrm{HCl}$ before and after phenol adsorption. 


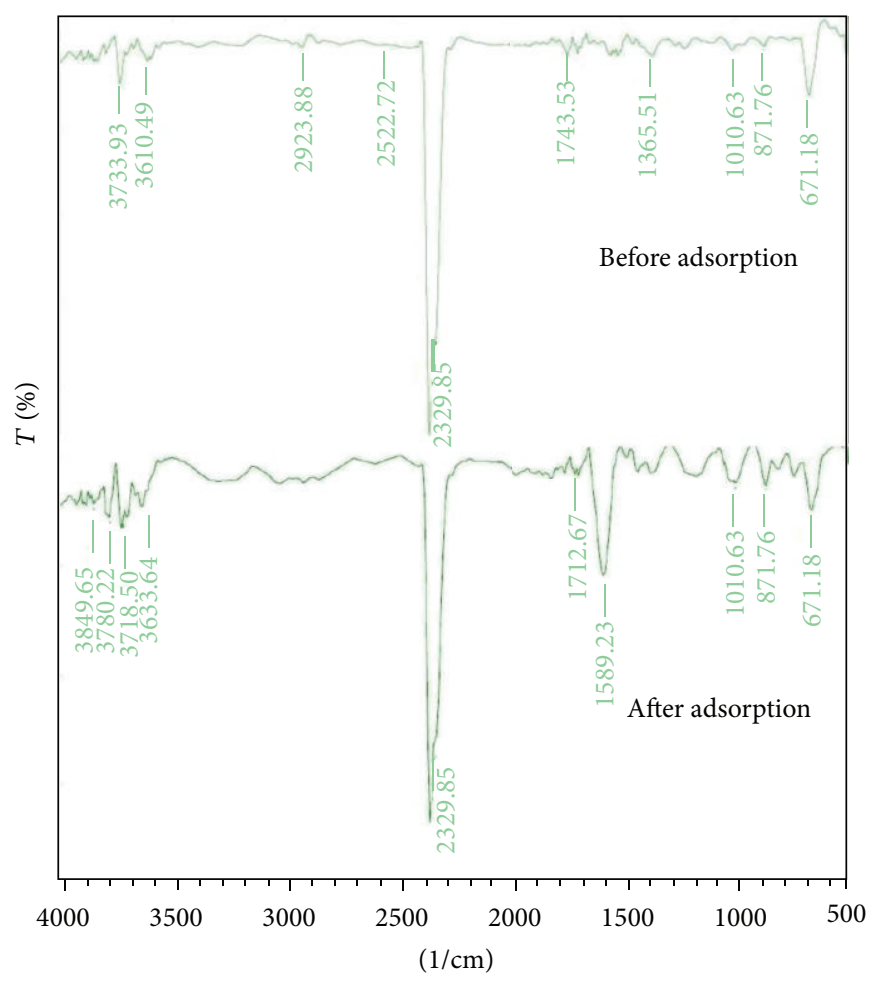

FIgURE 2: The FTIR spectra of adsorbent treated with $\mathrm{KOH}$ before and after phenol adsorption.

into phenoxide ion when $\mathrm{pH}>\mathrm{pKa}$. At higher $\mathrm{pH}$ values the concentration of the negatively charged phenoxide ion increases and the electrostatic repulsions occur between the negative surface charge of the carbon and the phenoxide anions in solution. At lower $\mathrm{pH}$ values, phenolic compounds are present as the unionized acidic compounds $[38,41]$ and thereby increased the electrostatic attractions between the phenol and the adsorption sites. It can be observed from Figure 3 that, up to $\mathrm{pH} 7$, the decrease in adsorption is gradual, which, however, drops drastically after $\mathrm{pH} 7$ for adsorbent treated with $\mathrm{HCl}$ because of repulsion between negatively charged carbon surface and phenoxide ions.

Similarly, from Figure 4, for adsorbent treated with $\mathrm{KOH}$ up to $\mathrm{pH} 8$, there was gradual decrease in adsorption and thereafter it decreased drastically. The optimum $\mathrm{pH}$ value was found to be 7.5 and 8.5 for adsorbent treated with $\mathrm{HCl}$ and $\mathrm{KOH}$, respectively. Similar results were reported in the literature $[35,42,43]$.

3.3. Effect of Adsorbent Dosage. To study the effect of adsorbent dose on phenol adsorption, the experiments were conducted at initial phenol concentration of $200 \mathrm{mg} / \mathrm{L}$. Figures 5 and 6 show the effect of carbon dose on the removal of phenol. It was observed that the \% removal increased with increase in adsorbent dose. After the equilibrium time, the removal was 58.6 to $89.6 \%$ for carbon dosage of 0.25 to $0.75 \mathrm{~g} / \mathrm{L}$ for adsorbent treated with $\mathrm{HCl}$ and there was 53.9 to $91.1 \%$ removal for adsorbent dosage of 0.25 to $1 \mathrm{~g} / \mathrm{L}$ for adsorbent treated with $\mathrm{KOH}$, respectively. The increase in phenol removal is due to the increase of the available sorption

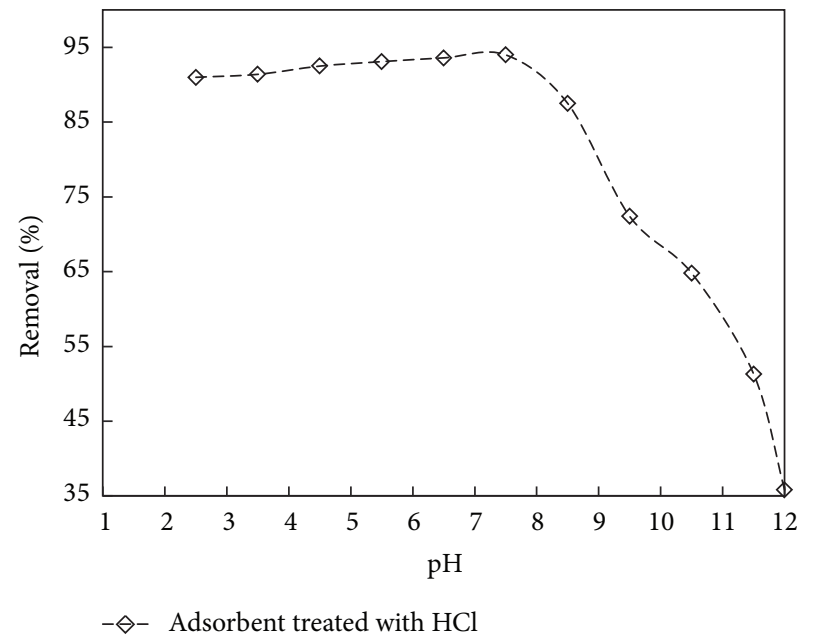

FIGURE 3: The effect of $\mathrm{pH}$ on \% removal for adsorbent treated with $\mathrm{HCl}$ (initial concentration: $150 \mathrm{mg} / \mathrm{L}$; volume: $200 \mathrm{~mL}$; dosage: $0.75 \mathrm{~g} / \mathrm{L})$.

surface and availability of more adsorption sites. It was also understood that, at higher carbon to solute concentration ratios, there is a higher sorption onto the adsorbent surface; thus it produces a lower solute concentration in the solution $[44,45]$. It was found that the optimum carbon dosage was $0.75 \mathrm{~g} / \mathrm{L}$ and $1 \mathrm{~g} / \mathrm{L}$ for adsorbent treated with $\mathrm{HCl}$ and $\mathrm{KOH}$, respectively. A similar observation was reported for removal of phenol from aqueous solution [21,46]. 


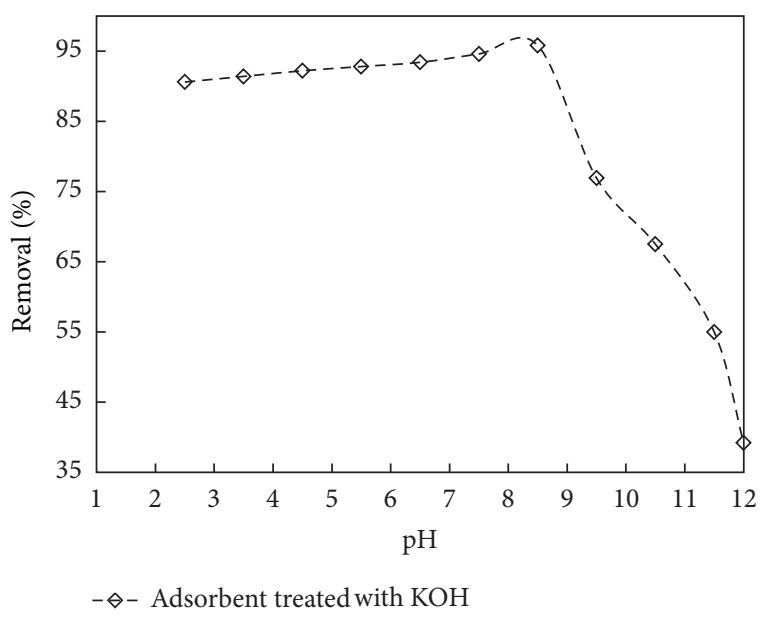

Figure 4: The effect of $\mathrm{pH}$ on \% removal for adsorbent treated with $\mathrm{KOH}$ (initial concentration: $150 \mathrm{mg} / \mathrm{L}$; volume: $200 \mathrm{~mL}$; dosage: $1 \mathrm{~g} / \mathrm{L})$.

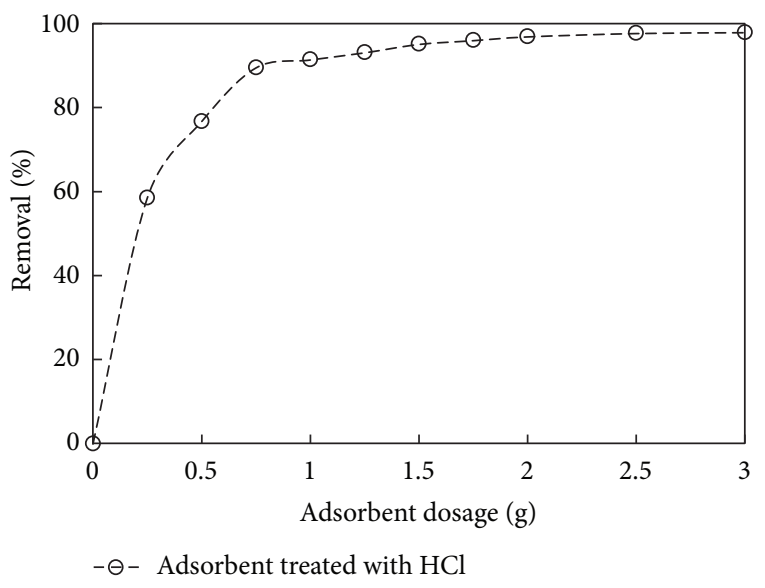

FIgURE 5: The effect of adsorbent dosage on \% removal for adsorbent treated with $\mathrm{HCl}$ (initial concentration: $150 \mathrm{mg} / \mathrm{L}$; volume: $200 \mathrm{~mL}$; $\mathrm{pH}: 7.5)$.

3.4. Effect of Contact Time and Initial Concentration. The initial concentration gives an important driving force required to overcome all mass transfer resistances of all molecules between the aqueous and solid phases [47]. The effect of initial phenol concentration on adsorption as shown in Figure 7 was studied in the range of $25-250 \mathrm{mg} / \mathrm{L}$ of the initial phenol concentrations under the optimized conditions. Figures 8 and 9 showed rapid adsorption of phenol in the period and thereafter the adsorption rate declined gradually and reached the equilibrium at about $6 \mathrm{~h}$ and $7 \mathrm{~h}$ for adsorbent treated with $\mathrm{HCl}$ and $\mathrm{KOH}$. It was observed that, at the initial stage, adsorption rate is more, because of availability of more numbers of vacant sites. After a certain period of time, the rate of adsorption decreases due to accumulation of adsorbate in the vacant sites. It was also found from the figure that the increase in initial phenol concentration enhances the interaction between phenol and active sites in carbon surface,

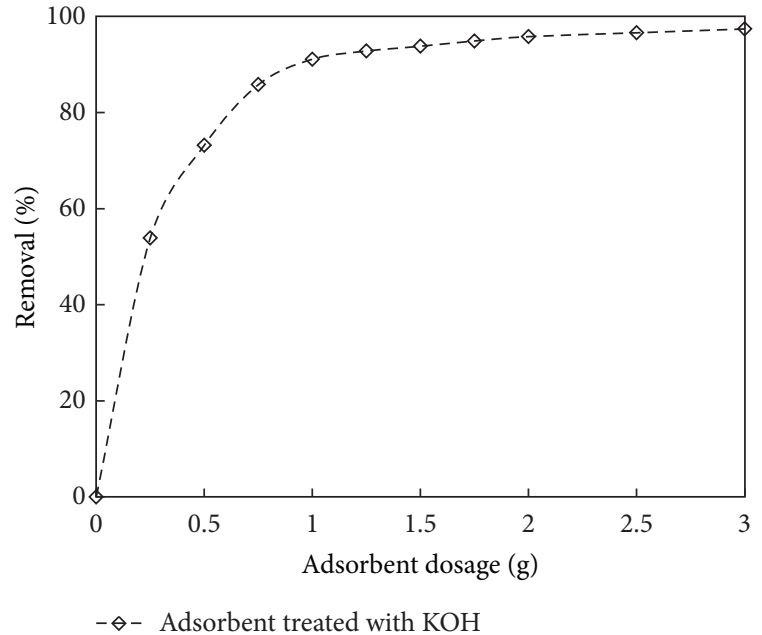

FIGURE 6: The effect of adsorbent dosage on \% removal for adsorbent treated with $\mathrm{KOH}$ (initial concentration: $150 \mathrm{mg} / \mathrm{L}$; volume: $200 \mathrm{~mL}$; $\mathrm{pH}: 8.5$ ).

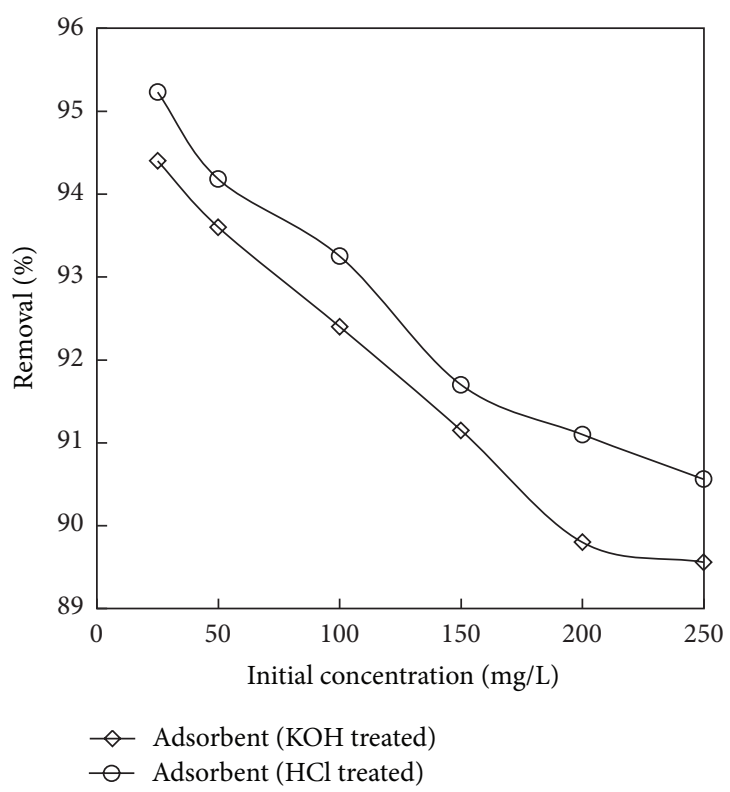

Figure 7: The plot showing the effect of initial concentration on \% removal for the adsorbents (the initial concentration: 25 to $250 \mathrm{mg} / \mathrm{L}$; dosage: $0.75 \mathrm{~g} / \mathrm{L}$ for adsorbent $(\mathrm{HCl})$ and $1 \mathrm{~g} / \mathrm{L}$ for adsorbent (KOH); volume: $200 \mathrm{~mL}$ ).

thus decreasing the \% removal of phenol with increase in concentration. Therefore, an increase in initial concentration of phenol decreased the adsorption uptake of phenol. Similar type of results was reported in $[48,49]$.

3.5. Effect of Temperature. The effect of temperature on the adsorption of phenol at various concentrations onto adsorbent treated with $\mathrm{HCl}$ and $\mathrm{KOH}$ is shown in Figures 10 and 11. Experiments were performed at different temperatures of $298,308,318$, and $328 \mathrm{~K}$. It can be observed from the figure 


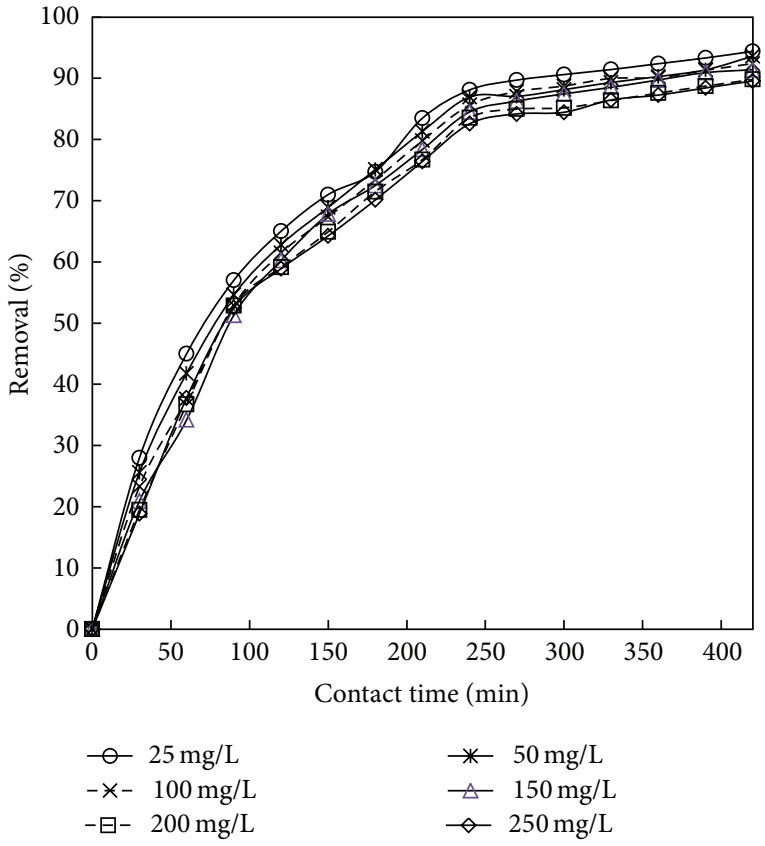

Figure 8: The plot showing the time v/s \% removal for adsorbent treated with $\mathrm{HCl}$ (the initial concentration: 25 to $250 \mathrm{mg} / \mathrm{L}$; dosage: $0.75 \mathrm{~g} / \mathrm{L}$; volume: $200 \mathrm{~mL}$ ).

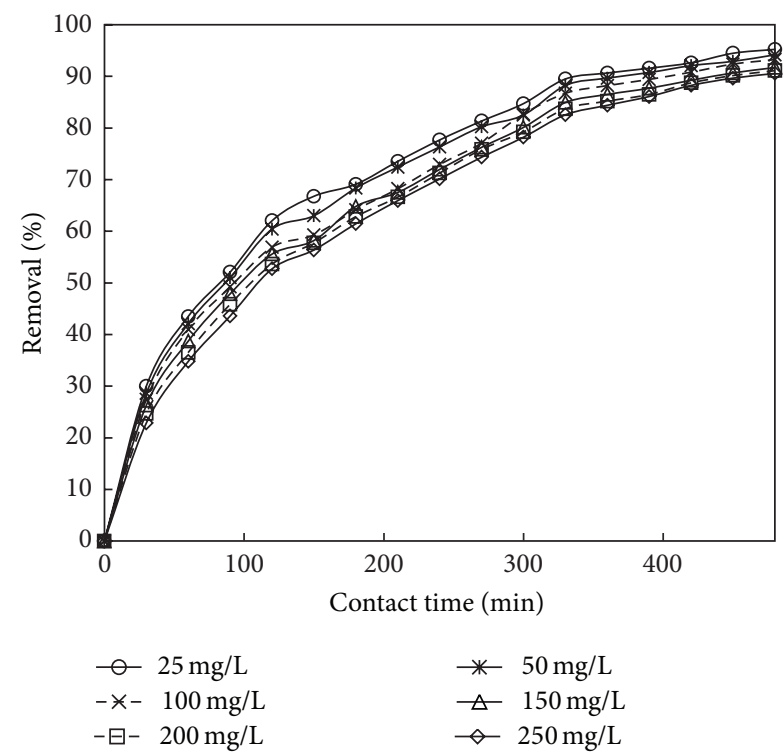

FIGURE 9: The plot showing the time v/s \% removal for adsorbent treated with $\mathrm{KOH}$ (the initial concentration: 25 to $250 \mathrm{mg} / \mathrm{L}$; dosage: $1 \mathrm{~g} / \mathrm{L}$; volume: $200 \mathrm{~mL}$ ).

that the $\%$ removal of phenol decreased with the increase in temperature from 298 to $328 \mathrm{~K}$. This is probably due to the decreased chemical interaction between adsorbates and adsorbent indicating the exothermic nature of the adsorption process. Therefore, further adsorption experiments were performed at $298 \mathrm{~K}$. Similar trend was obtained in works reported by $[23,35]$.

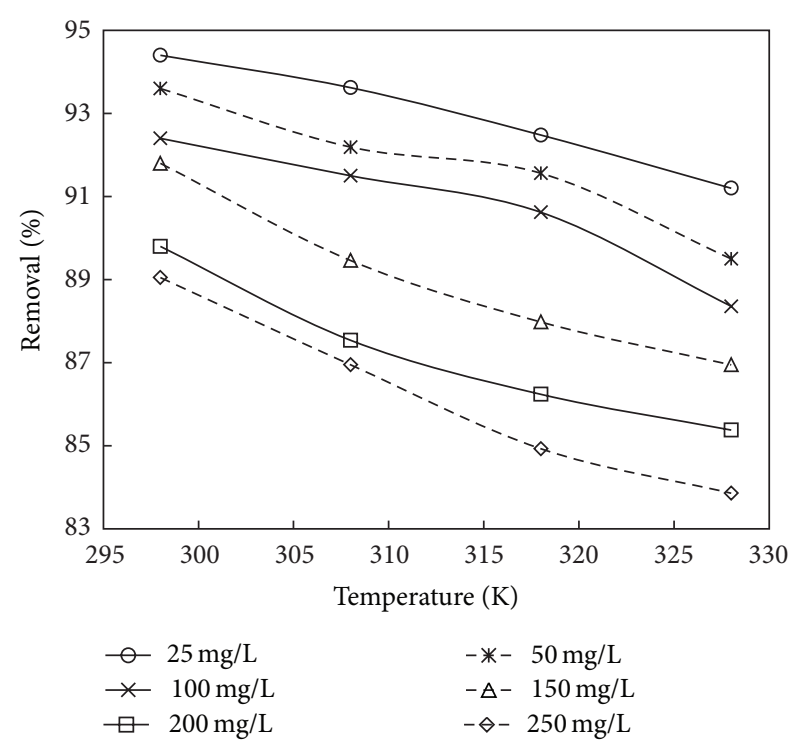

FIGURE 10: The plot showing the effect of temperature on $\%$ removal for adsorbent treated with $\mathrm{HCl}$ (the initial concentration: 25 to $250 \mathrm{mg} / \mathrm{L}$; dosage: $0.75 \mathrm{~g} / \mathrm{L}$; volume: $200 \mathrm{~mL}$ ).

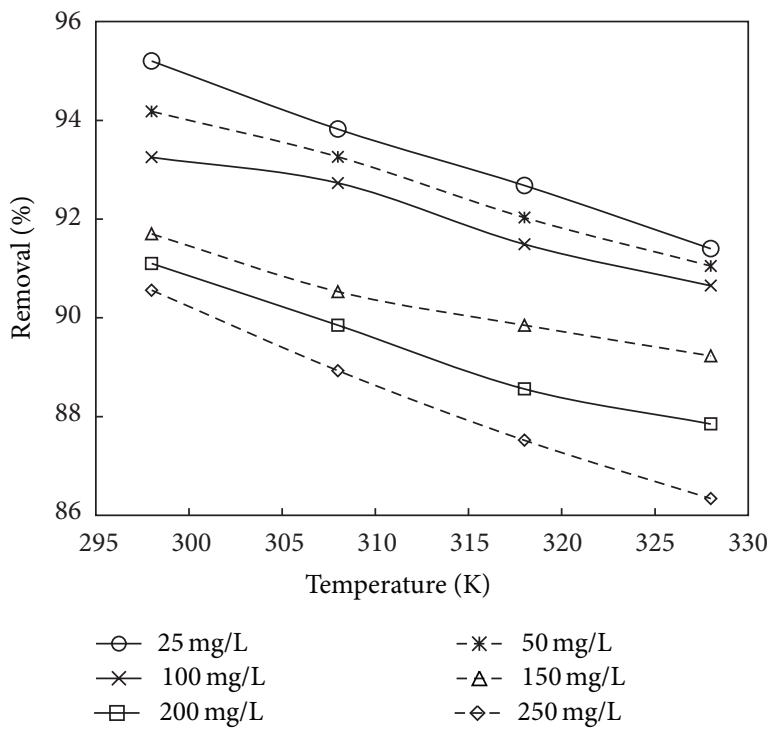

FIGURE 11: The plot showing the effect of temperature on \% removal for adsorbent treated with $\mathrm{KOH}$ (the initial concentration: 25 to $250 \mathrm{mg} / \mathrm{L}$; dosage: $1 \mathrm{~g} / \mathrm{L}$; volume: $200 \mathrm{~mL}$ ).

3.6. Isotherm Studies. Adsorption isotherm describes the relationship between the amount of a solute adsorbed and its concentration in the equilibrium solution at a constant temperature. Adsorption isotherm is important to understand the solute-adsorbent interactions and optimization of the use of adsorbents. Several models have been investigated in the literature to describe experimental data of adsorption isotherm. The equilibrium isotherms like Langmuir, Freundlich, Temkin, and Dubinin-Radushkevich isotherms were analysed in this study. A trial and error procedure was employed to estimate the above isotherms parameters by 
TABLE 6: Table showing the nature of the process depending on the value of separation factor $\left(R_{L}\right)$.

\begin{tabular}{lc}
\hline$R_{L}>1$ & Unfavourable \\
$R_{L}=1$ & Linear \\
$0<R_{L}<1$ & Favourable \\
$R_{L}=0$ & Irreversible \\
\hline
\end{tabular}

minimizing the error distribution between experimental data and predicted data using the solver add-in with Microsoft's Excel [49].

The Langmuir isotherm is based on the assumption that the adsorption process will take place uniformly within the adsorbent surface and with uniform distribution of energy level [50]. Once the adsorbate is attached on the site, no more adsorption takes place, showing that it is monolayer type of adsorption.

The Langmuir isotherm is

$$
q_{e}=\frac{q_{m} K_{a} C_{e}}{1+K_{a} C_{e}},
$$

where $q_{m}(\mathrm{mg} / \mathrm{g})$ and $K_{a}(\mathrm{~L} / \mathrm{mg})$ are the Langmuir isotherm constants.

The Langmuir isotherm can also be expressed by a separation factor $\left(R_{L}\right)$, which is given by the equation

$$
R_{L}=\frac{1}{\left(1+b C_{0}\right)},
$$

where " $C_{0}$ " is the initial concentration of phenol in $\mathrm{mg} / \mathrm{L}$ and " $b$ " is the Langmuir constant in $\mathrm{L} / \mathrm{mg}$. The separation factor " $R_{L}$ " indicates the nature of the adsorption process [46] as given in Table 6.

The $R_{L}$ values were found to be varying from 0.091933 to 0.503081 and 0.093897 to 0.508906 for adsorbent treated with $\mathrm{HCl}$ and $\mathrm{KOH}$, respectively, showing that the adsorption process is favourable.

Freundlich isotherm [51] explains that the adsorption occurs on heterogeneous sites with nonuniform distribution of energy level and it also proposes reversible adsorption and possibility of adsorption on multilayers:

$$
q_{e}=k_{f} C_{e}{ }^{1 / n},
$$

where $q_{e}$ is the amount of adsorbate adsorbed at equilibrium $(\mathrm{mg} / \mathrm{g}), C_{e}$ is equilibrium concentration of the adsorbate $(\mathrm{mg} / \mathrm{L}), K_{F}$ is Freundlich constant $(\mathrm{mg} / \mathrm{g})(\mathrm{L} / \mathrm{mg})^{1 / n}$, and $1 / n$ is adsorption intensity. The value of adsorption intensity shows the favourability of adsorption [52]. The value of $n>1$ expresses favourable adsorption condition.

Temkin isotherm $[53,54]$ includes the influences of indirect adsorbate/adsorbate interactions on adsorption isotherms and explains that because of these interactions the heat of adsorption of all the molecules in the layer would decrease linearly with coverage.

The Temkin isotherm has been used in the following form:

$$
q_{e}=B \ln A C_{e},
$$

where $A$ and $B$ are Temkin isotherm constants.

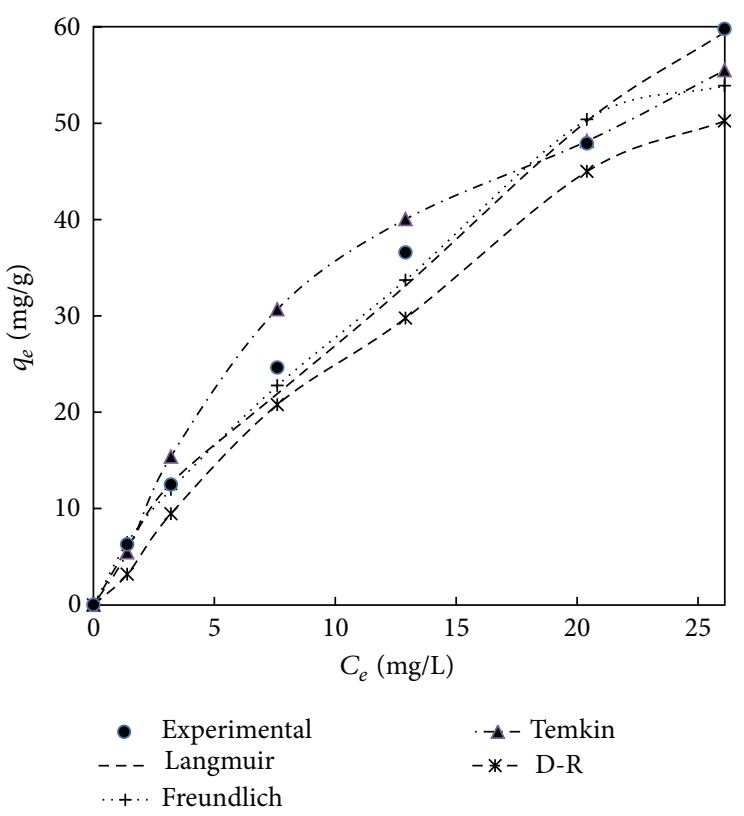

FIGURE 12: The comparison of various isotherm models for adsorbent treated with $\mathrm{HCl}$.

The Dubinin-Radushkevich model [55] which is used to estimate the apparent free energy of adsorption has the following form:

$$
q_{e}=q_{m} e^{\beta \varepsilon^{2}},
$$

where $q_{m}$ is the Dubinin-Radushkevich monolayer capacity $(\mathrm{mg} / \mathrm{g}), \beta$ is a constant related to sorption energy, and $\varepsilon$ is the Polanyi potential which is related to the equilibrium concentration in the following form:

$$
\varepsilon=R T \ln \left(1+\frac{1}{C_{e}}\right),
$$

where $R$ is the gas constant $(8.314 \mathrm{~J} / \mathrm{mol} \mathrm{K})$ and $T$ is the absolute temperature. The constant $\beta$ gives the mean free energy, $E$, of sorption per molecule of the sorbate and is given by the relation

$$
E=\frac{1}{\sqrt{2 \beta}} .
$$

The calculated isotherm constants by nonlinear method are represented in Tables 7 and 8 and the experimental equilibrium data and the predicted theoretical isotherms for the adsorption of adsorbent treated with $\mathrm{HCl}$ and $\mathrm{KOH}$ are shown in Figures 12 and 13. It can be observed from Figures 12 and 13 that Langmuir isotherm model is the best fit model when compared to Freundlich, Temkin, and DubininRadushkevich isotherm model for adsorbent treated with both $\mathrm{HCl}$ and $\mathrm{KOH}$. This is proved by the high value of correlation coefficient in case of Langmuir models compared to the other isotherm models. This concludes the fact that the 
TABLE 7: The various parameters and the model equation for adsorbent treated with HCl.

\begin{tabular}{lccc}
\hline Isotherm model & Model parameter & $R^{2}$ & Model equation \\
\hline Langmuir & $Q_{m}=112.5$ & 0.9955 & $q_{e}=\frac{4.37 C_{e}}{1+0.03851 C_{e}}$ \\
\hline Freundlich & $K_{f}=0.03951$ & 0.9869 & $q_{e}=1.3468 C_{e}^{0.198}$ \\
\hline \multirow{2}{*}{ Temkin } & $K_{f}=1.3468$ \\
$n=5.048$ & 0.91827 & $q_{e}=17.67 \ln \left(0.7471 C_{e}\right)$ \\
\hline \multirow{2}{*}{ D-R } & $\begin{array}{c}A=0.7471 \\
B=17.67\end{array}$ & 0.9323 & $q_{e}=60 * e^{-\left(2 \times 10^{-5} * \varepsilon^{2}\right)}$ \\
\hline
\end{tabular}

TABLE 8: The various parameters and the model equation for adsorbent treated with $\mathrm{HCl}$.

\begin{tabular}{lccc}
\hline Isotherm model & Model parameter & $R^{2}$ & Model equation \\
\hline Langmuir & $\begin{array}{c}Q_{m}=91.07 \\
K_{f}=0.0386\end{array}$ & 0.9964 & $q_{e}=\frac{3.515 C_{e}}{1+0.0386 C_{e}}$ \\
\hline \multirow{2}{*}{ Freundlich } & $\begin{array}{c}K_{f}=1.326 \\
n=4.198\end{array}$ & 0.9811 & $q_{e}=1.326 C_{e} 0.2382$ \\
\hline Temkin & $\begin{array}{c}A=0.852 \\
B=13.194\end{array}$ & 0.90717 & $q_{e}=13.194 \ln \left(0.852 C_{e}\right)$ \\
\hline \multirow{2}{*}{ D-R } & $\begin{array}{l}Q_{m}=46 \\
\end{array}$ & Beta $=0.85 \times 10^{-5}$ \\
$E=242.535$ & 0.9283 & $q_{e}=46 * e^{-\left(0.85 \times 10^{-5} * \varepsilon^{2}\right)}$ \\
\hline
\end{tabular}

TABLE 9: Comparison of monolayer adsorption capacity for phenol onto other various adsorbents.

\begin{tabular}{lcc}
\hline Adsorbent & $q_{m}(\mathrm{mg} / \mathrm{g})$ & Reference \\
\hline Date stones & 90.3 & {$[17]$} \\
Tamarindus indica & 80 & {$[18]$} \\
Vegetal cords & 6.21 & {$[19]$} \\
Banana peel & 688.9 & {$[20]$} \\
Palm seed coat & 18.3 & {$[21]$} \\
Oil palm empty fruit bunch & 4.868 & {$[22]$} \\
Date pit & 262.3 & {$[23]$} \\
Black stone cherries & 133.33 & {$[24]$} \\
Vetiver roots & 145 & {$[25]$} \\
Sugarcane bagasse & 35.71 & {$[26]$} \\
Luffa cylindrica & 9.25 & {$[27]$} \\
Lantana camara (HCl treated) & 112.5 & Present work \\
Lantana camara (KOH treated) & 91.07 & Present work \\
\hline
\end{tabular}

adsorbent treated with both $\mathrm{HCl}$ and $\mathrm{KOH}$ follows monolayer adsorption on a surface that is homogenous. From the Tables 7 and 8 , we can also get the maximum monolayer adsorption capacity $\left(q_{m}\right)$ of $112.5 \mathrm{mg} / \mathrm{g}$ and $91.07 \mathrm{mg} / \mathrm{g}$ for adsorbent treated with $\mathrm{HCl}$ and $\mathrm{KOH}$, respectively.

The comparison of maximum monolayer adsorption capacity of phenol onto various agricultural adsorbents from the literature is presented in Table 9.

3.7. Thermodynamic Study. The feasibility of the adsorption process was estimated by the determination of thermodynamic parameters like free energy change $\left(\Delta G^{\circ}\right)$, enthalpy

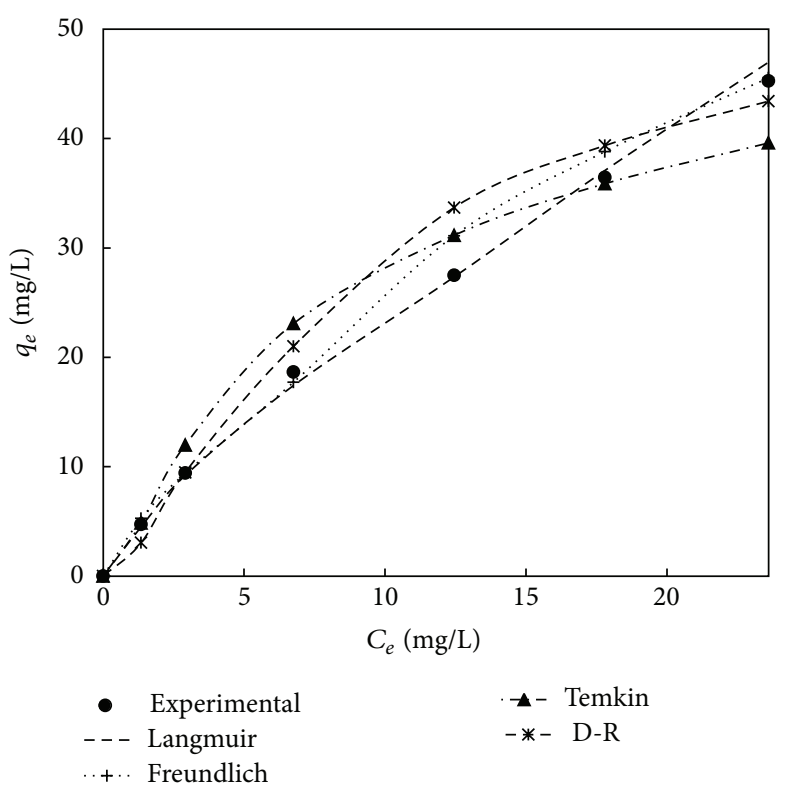

FIGURE 13: The comparison of various isotherm models for adsorbent treated with $\mathrm{KOH}$.

$\left(\Delta H^{\circ}\right)$, and entropy $\left(\Delta S^{\circ}\right)$ which are calculated from the following equation:

$$
\begin{gathered}
K_{c}=\frac{C_{A e}}{C_{e}}, \\
\Delta G^{\circ}=-R T \ln K_{c},
\end{gathered}
$$


TABLE 10: The determined thermodynamic parameters for adsorbent treated with $\mathrm{HCl}$.

\begin{tabular}{lcccccc}
\hline $\begin{array}{l}\text { Conc. } \\
\mathrm{mg} / \mathrm{L}\end{array}$ & $\Delta G^{\circ}(\mathrm{J} / \mathrm{mol})$ & $\Delta G^{\circ}(\mathrm{J} / \mathrm{mol})$ & $\Delta G^{\circ}(\mathrm{J} / \mathrm{mol})$ & $\Delta G^{\circ}(\mathrm{J} / \mathrm{mol})$ & $\Delta H^{\circ}(\mathrm{J} / \mathrm{mol})$ & $\Delta S^{\circ}(\mathrm{J} / \mathrm{mol} \mathrm{K})$ \\
\hline 25 & $298 \mathrm{~K}$ & $308 \mathrm{~K}$ & $318 \mathrm{~K}$ & $328 \mathrm{~K}$ & -29.54 \\
50 & -7077.08 & -6781.68 & -6486.28 & -6190.88 & -15880.00 & -26.54 \\
100 & -6623.08 & -6357.68 & -6092.28 & -5826.88 & -14532.00 & -20.266 \\
150 & -6248.73 & -6046.07 & -5843.41 & -5640.75 & -12288.00 & -19.1 \\
200 & -5748.2 & -5557.2 & -5366.2 & -5175.2 & -11440.00 & -17.15 \\
250 & -5339.3 & -5167.8 & -4996.3 & -4824.8 & -10450.00 & -16.304 \\
\hline
\end{tabular}

TABLE 11: The determined thermodynamic parameters for adsorbent treated with $\mathrm{KOH}$.

\begin{tabular}{|c|c|c|c|c|c|c|}
\hline $\begin{array}{l}\text { Conc. } \\
\mathrm{mg} / \mathrm{L}\end{array}$ & $\begin{array}{c}\Delta G^{\circ}(\mathrm{J} / \mathrm{mol}) \\
298 \mathrm{~K}\end{array}$ & $\begin{array}{c}\Delta G^{\circ}(\mathrm{J} / \mathrm{mol}) \\
308 \mathrm{~K}\end{array}$ & $\begin{array}{c}\Delta G^{\circ}(\mathrm{J} / \mathrm{mol}) \\
318 \mathrm{~K}\end{array}$ & $\begin{array}{c}\Delta G^{\circ}(\mathrm{J} / \mathrm{mol}) \\
328 \mathrm{~K}\end{array}$ & $\Delta H^{\circ}(\mathrm{J} / \mathrm{mol})$ & $\Delta S^{\circ}(\mathrm{J} / \mathrm{mol} \mathrm{K})$ \\
\hline 25 & -7352.88 & -7038.48 & -6724.08 & -6409.68 & -16722 & -31.44 \\
\hline 50 & -6901.54 & -6703.84 & -6506.14 & -6308.44 & -12793 & -19.77 \\
\hline 100 & -6548.55 & -6432.63 & -6316.71 & -6200.79 & -10003 & -11.5921 \\
\hline 150 & -5976.61 & -5871.5 & -5766.4 & -5661.29 & -9108.8 & -10.5107 \\
\hline 200 & -5738.52 & -5640.32 & -5542.13 & -5443.94 & -8664.7 & -9.8194 \\
\hline 250 & -5498.06 & -5415.18 & -5332.29 & -5249.41 & -7968 & -8.28839 \\
\hline
\end{tabular}

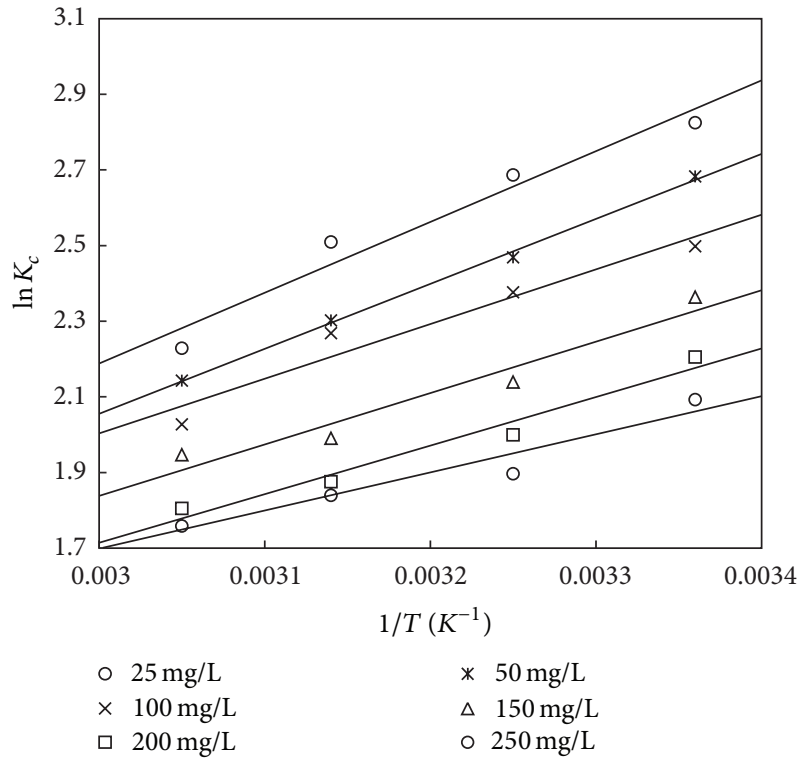

FIgURE 14: The van't Hoff plot for adsorbent treated with $\mathrm{HCl}$.

$$
\begin{aligned}
& \Delta G^{\circ}=\Delta H^{\circ}-T \Delta S^{\circ}, \\
& \ln K_{c}=\frac{\Delta S^{\circ}}{R}-\frac{\Delta S^{\circ}}{R T},
\end{aligned}
$$

where $K_{c}$ is the equilibrium constant, $C_{e}$ is the equilibrium concentration in solution $(\mathrm{mg} / \mathrm{L})$, and $C_{A e}$ is the amount of phenol adsorbed on the adsorbent per liter of solution at equilibrium $(\mathrm{mg} / \mathrm{L}) . \Delta G^{\circ}, \Delta H^{\circ}$, and $\Delta S^{\circ}$ are changes in Gibbs free energy $(\mathrm{kJ} / \mathrm{mol})$, enthalpy $(\mathrm{kJ} / \mathrm{mol})$, and entropy $(\mathrm{J} / \mathrm{mol} \mathrm{K})$, respectively, $R$ is the gas constant $(8.314 \mathrm{~J} / \mathrm{mol} K)$, and $T$ is the temperature $(K)$. The values of $\Delta H^{\circ}$ and $\Delta S^{\circ}$

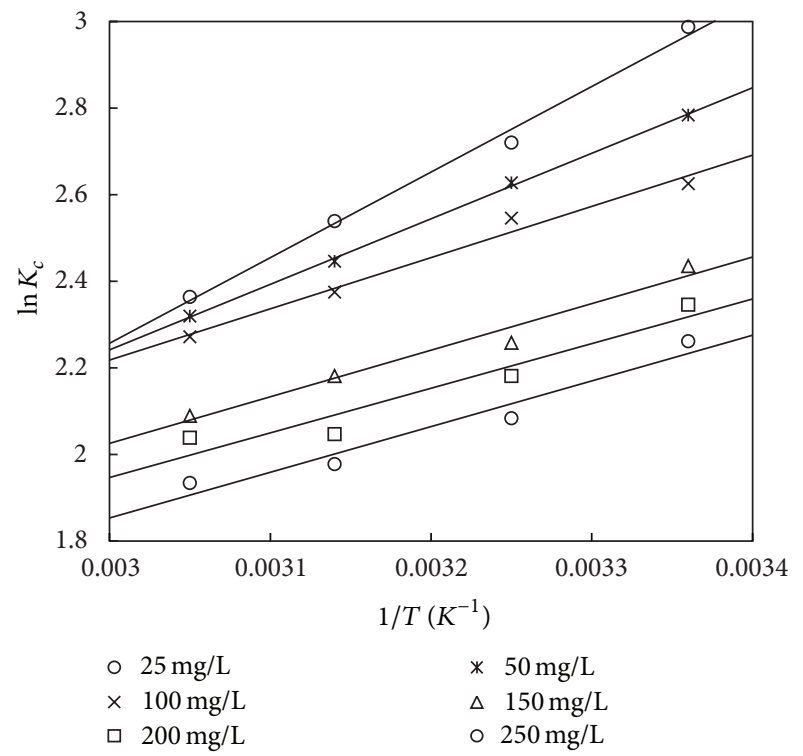

FIgURE 15: The van't Hoff plot for the adsorbent treated with $\mathrm{KOH}$.

are determined from the slope and the interception of the plots of $\ln K_{c}$ versus $1 / T$ (Figures 14 and 15) and are shown in Tables 10 and 11. The negative values of $\Delta G^{\circ}$ in the temperature range of 298 to $328 \mathrm{~K}$ show that the adsorption process is feasible and spontaneous. The negative value of $\Delta H^{\circ}$ confirmed that the adsorption process is exothermic in nature. The negative value of $\Delta S^{\circ}$ indicates the reduced randomness at the adsorbent/solution interface during the process of adsorption. It can also be observed that, at lower initial concentration, the values of $\Delta G^{\circ}$ and $\Delta H^{\circ}$ are more negative showing that the process is feasible and exothermic in nature. Similar nature of results was obtained in works of $[35,45,55,56]$. 
TABLE 12: The kinetic constants of first-order and second-order for adsorbent ( $\mathrm{HCl}$ treated).

\begin{tabular}{lcccccccc}
\hline $\begin{array}{l}\text { Conc. } \\
(\mathrm{mg} / \mathrm{L})\end{array}$ & $Q_{e, \exp }(\mathrm{mg} / \mathrm{g})$ & $K_{1} * 10^{3}\left(\mathrm{~min}^{-1}\right)$ & $Q_{e, \text { cal }}(\mathrm{mg} / \mathrm{g})$ & $R^{2}$ & $Q_{e, \text { cal }}(\mathrm{mg} / \mathrm{g})$ & $K_{2} * 10^{4}(\mathrm{~g} / \mathrm{mg} \cdot \mathrm{min})$ & $h(\mathrm{mg} / \mathrm{g} \cdot \mathrm{min})$ & $R^{2}$ \\
\hline 25 & 6.2933 & 9.78 & 7.3329 & 0.96574 & 6.82 & 24.90 & 0.1158 & 0.99732 \\
50 & 12.48 & 8.5211 & 13.0785 & 0.9729 & 14.16 & 7.98 & 0.1594 & 0.99327 \\
100 & 24.64 & 10.20 & 33.148 & 0.95395 & 33.79 & 2.26 & 0.2580 & 0.99569 \\
150 & 36.56 & 9.9489 & 51.394 & 0.97226 & 46.30 & 1.65 & 0.3537 \\
200 & 47.89 & 9.327 & 60.52 & 0.96477 & 56.445 & 1.50 & 0.987 \\
250 & 59.7 & 11.51 & 73.9 & 0.9541 & 64.3 & 1.48 & 0.4779 & 0.99053 \\
\hline
\end{tabular}

TABLE 13: The kinetic constants of first-order and second-order for adsorbent (KOH treated).

\begin{tabular}{|c|c|c|c|c|c|c|c|c|}
\hline \multirow{2}{*}{$\begin{array}{l}\text { Conc. } \\
\text { (mg/L) }\end{array}$} & \multicolumn{4}{|c|}{ First-order kinetic } & \multicolumn{4}{|c|}{ Second-order kinetic } \\
\hline & $Q_{e, \exp }(\mathrm{mg} / \mathrm{g})$ & $K_{1} * 10^{3}\left(\min ^{-1}\right)$ & $Q_{e, \mathrm{cal}}(\mathrm{mg} / \mathrm{g})$ & $R^{2}$ & $Q_{e, \mathrm{cal}}(\mathrm{mg} / \mathrm{g})$ & $K_{2} * 10^{3}(\mathrm{~g} / \mathrm{mg} \cdot \mathrm{min})$ & $h(\mathrm{mg} / \mathrm{g} \cdot \mathrm{min})$ & $R^{2}$ \\
\hline 25 & 4.76 & 6.49 & 3.8939 & 0.98778 & 5.27 & 2.23 & 0.06193 & 0.9958 \\
\hline 50 & 9.418 & 6.07 & 7.5262 & 0.98794 & 10.593 & 1.024 & 0.1149 & 0.9939 \\
\hline 100 & 18.65 & 6.033 & 15.85 & 0.96661 & 20.24 & 0.540 & 0.2212 & 0.9916 \\
\hline 150 & 27.51 & 5.987 & 23.36 & 0.98688 & 29.152 & 0.3617 & 0.3073 & 0.9913 \\
\hline 200 & 36.44 & 6.033 & 32.32 & 0.9836 & 37.9836 & 0.246 & 0.3549 & 0.9925 \\
\hline 250 & 45.28 & 5.941 & 40.49 & 0.98846 & 47.347 & 0.1733 & 0.38838 & 0.9944 \\
\hline
\end{tabular}

3.8. Kinetics of the Adsorption. Adsorption kinetics has been examined to determine the adsorption mechanism. The various kinetic models reported that adsorption depends on the chemical nature of adsorbent, experimental conditions, and the mass transfer process. Therefore, in order to investigate the mechanism of present adsorption process and the ratedetermining step, the different kinetic models like pseudofirst-order, pseudo-second-order, and intraparticle diffusion model were verified and the adsorption capacities were found.

The pseudo-first-order kinetic model in linear form is given by Lagergren [57]

$$
\log \left(q_{e}-q_{t}\right)=\log q_{e}-\frac{k_{\mathrm{ad}}}{2.303} t
$$

where $q_{t}$ is the adsorption capacity at time $t(\mathrm{mg} / \mathrm{g})$ and $\operatorname{kad}\left(\mathrm{min}^{-1}\right)$ is the rate constant of the pseudo-first-order adsorption. The rate constant $k_{\text {ad }}$, adsorption capacity $q_{e}$, and the correlation coefficients were obtained from the linear plots of $\log \left(q_{e}-q_{t}\right)$ versus $t$ (as shown in Figures 16 and 17). The obtained values of $q_{e}$ and $K_{\mathrm{ad}}$ and the corresponding linear regression correlation coefficient are shown in Tables 12 and 13. It was investigated that the correlation coefficients for the pseudo-first-order kinetic model for the adsorbent treated with both $\mathrm{HCl}$ and $\mathrm{KOH}$ are low. It was also observed that the values of calculated adsorption capacity and the experimental values deviated to a large extent, showing a poor fitting of experimental data to pseudo-first-order kinetic model. [58]

The pseudo-second-order kinetic model is given by Ho

$$
\frac{t}{q_{t}}=\frac{1}{h}+\frac{1}{q_{e}} t,
$$

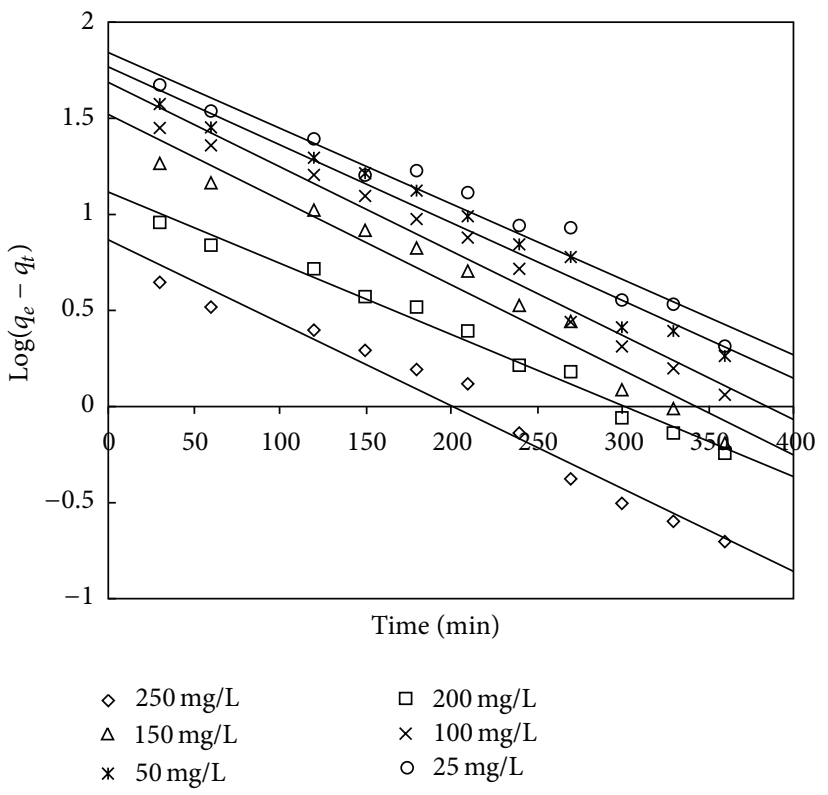

FIGURE 16: First-order kinetic plot for adsorbent treated with $\mathrm{HCl}$.

where $h=k q_{e}^{2}\left(\mathrm{mg} \mathrm{g}^{-1} \mathrm{~min}^{-1}\right)$ is the initial adsorption rate and $k$ is the rate constant of pseudo-second-order model ( $g$ $\left.\mathrm{mg}^{-1} \mathrm{~min}^{-1}\right)$. The values of $q_{e}, k$, and $h$ are obtained from the linear plot of $t / q_{t}$ versus $t$ shown in Figures 18 and 19. The values of experimental and calculated $q_{e}$ along with correlation coefficient are presented in Tables 12 and 13. It can be observed from Tables 12 and 13 that, for the adsorbent treated with both $\mathrm{HCl}$ and $\mathrm{KOH}$, the adsorption kinetics is better represented by pseudo-second-order kinetic model. This suggests that the rate controlling step of phenol onto 


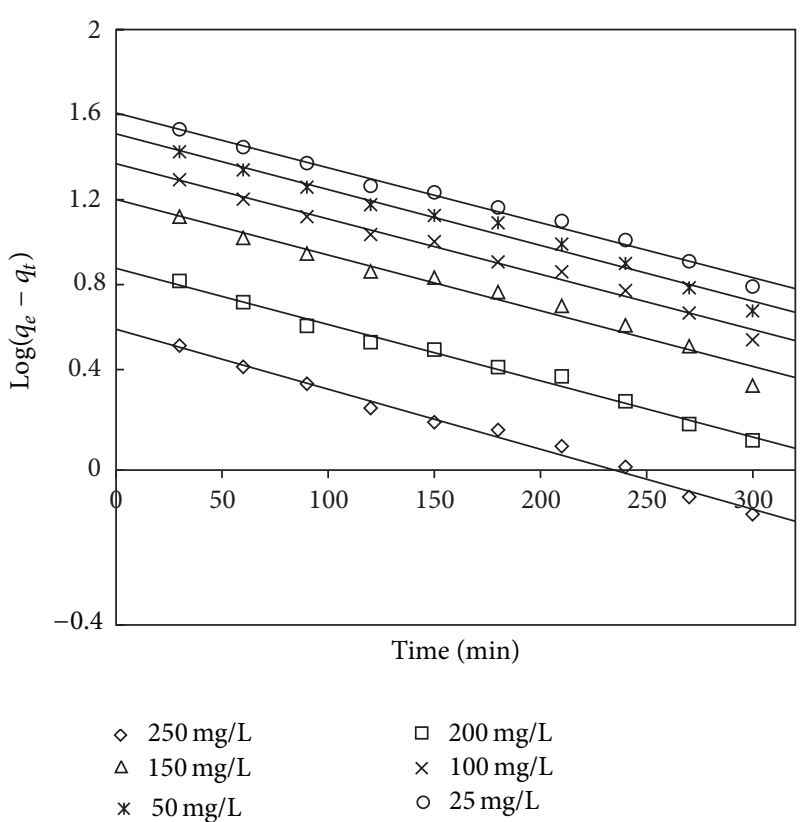

FIGURE 17: First-order kinetic plot for adsorbent treated with $\mathrm{KOH}$.

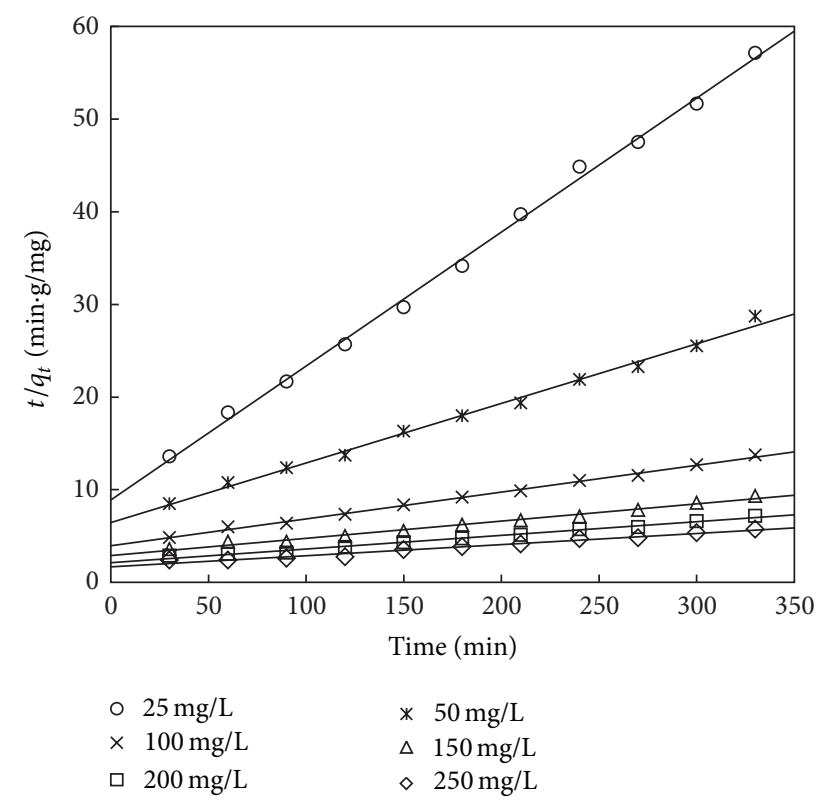

FIGURE 18: Second-order kinetic plot for adsorbent treated with $\mathrm{HCl}$.

adsorbent may be by chemisorption. From Tables 12 and 13, it was also found that the values of the rate constant $k$ decreased with increasing initial phenol concentration for the pseudosecond-order model. This may be because of the reason that there is less competition for the active sites at lower concentration and high competition exists at the surface sites at higher concentrations. A similar result was reported for the adsorption of phenol from aqueous solution in banana peel [20], date pit carbon [23], coconut shell carbon, [16] and biomass material [41].

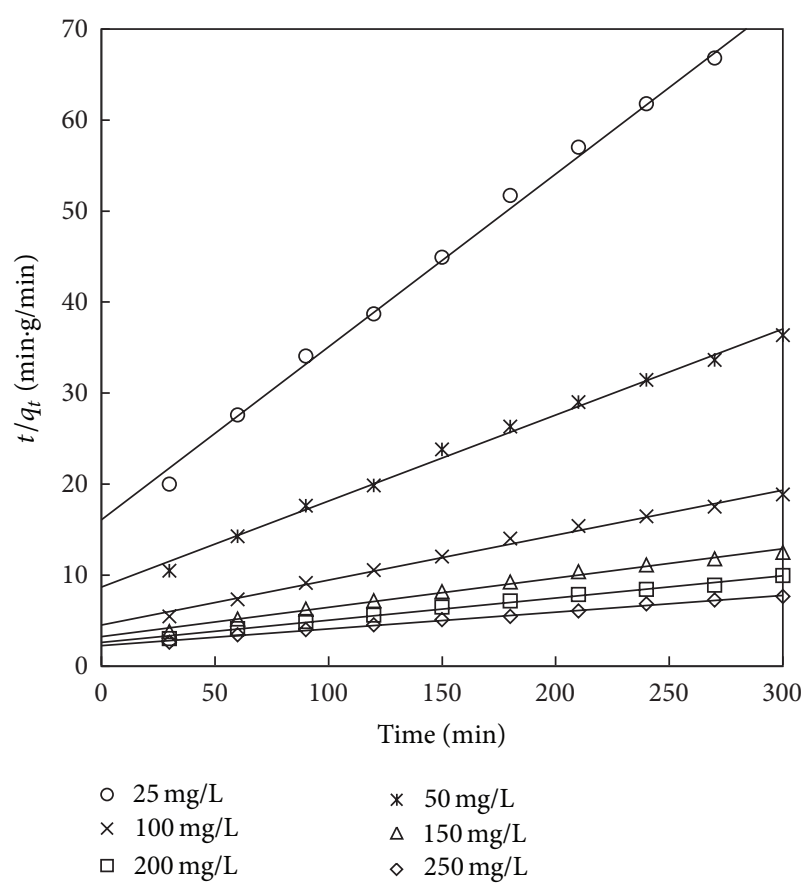

FIGURE 19: Second-order kinetic model for adsorbent treated with $\mathrm{KOH}$.

TABLE 14: The kinetics constants of intraparticle diffusion of adsorbent ( $\mathrm{HCl}$ treated).

\begin{tabular}{lccc}
\hline \multirow{2}{*}{ Conc. $(\mathrm{mg} / \mathrm{L})$} & \multicolumn{3}{c}{ Intraparticle diffusion } \\
& $K_{i}\left(\mathrm{mg} / \mathrm{g} \cdot \mathrm{min}^{0.5}\right)$ & $c$ & $R^{2}$ \\
\hline 25 & 0.31785 & 0.63245 & 0.94971 \\
50 & 0.62941 & 1.0110 & 0.94412 \\
100 & 1.34986 & 1.0986 & 0.95896 \\
150 & 2.0777 & 1.210 & 0.94795 \\
200 & 2.688 & 1.293 & 0.95319 \\
250 & 3.31 & 1.3514 & 0.96728 \\
\hline
\end{tabular}

The kinetic data can be analysed using the Weber and Morris model [59] to understand the diffusion mechanism:

$$
q_{t}=k_{p} t^{1 / 2}+c
$$

where $c$ is the interception and $k_{p}$ is the intraparticle diffusion rate constant which are obtained from the linear plot of uptake $\left(q_{t}\right)$ versus the square root of time $\left(t^{1 / 2}\right)$ which is shown in Figures 20 and 21. The interception shows the boundary layer thickness; that is, the larger the interception, the greater the boundary layer effect. The calculated intraparticle diffusion coefficient $k_{p}$ values are listed in Tables 14 and 15.

If the $q_{t}$ versus $t^{1 / 2}$ plot is linear and passes through the origin, then only the intraparticle diffusion is the rate controlling mechanism. Otherwise, some other mechanisms along with intraparticle diffusion are also involved [60]. As can be seen from Figures 20 and 21, the interception of the line does not pass through the origin showing that the mechanism 
TABLE 15: The kinetics constants of intraparticle diffusion of adsorbent ( $\mathrm{KOH}$ treated).

\begin{tabular}{lccc}
\hline \multirow{2}{*}{ Conc. $(\mathrm{mg} / \mathrm{L})$} & \multicolumn{3}{c}{ Intraparticle diffusion } \\
& $K_{i}\left(\mathrm{mg} / \mathrm{g} \cdot \mathrm{min}^{0.5}\right)$ & $c$ & $R^{2}$ \\
\hline 25 & 0.22104 & 0.473 & 0.97884 \\
50 & 0.4467 & 0.752 & 0.98516 \\
100 & 0.873 & 1.226 & 0.98991 \\
150 & 1.361 & 1.284 & 0.99031 \\
200 & 1.78213 & 1.37983 & 0.99469 \\
250 & 2.21113 & 1.39943 & 0.99499 \\
\hline
\end{tabular}

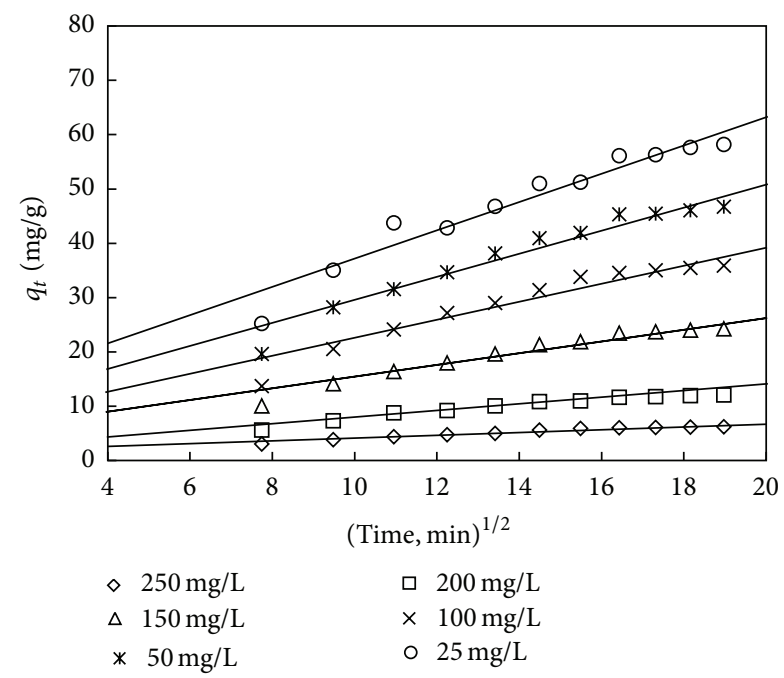

FIGURE 20: Intraparticle diffusion plot for adsorbent treated with $\mathrm{HCl}$.

of adsorption is not solely govern ed by intraparticle diffusion process.

To investigate the slow step in the adsorption process, the kinetic data were further studied using the Boyd model given by [38]

$$
\begin{gathered}
F=1-\frac{6}{\pi^{2}} \exp \left(-B_{t}\right), \\
F=\frac{q_{t}}{q_{e}},
\end{gathered}
$$

where $q_{e}(\mathrm{mg} / \mathrm{g})$ is the adsorption capacity at the equilibrium time and $q_{t}(\mathrm{mg} / \mathrm{g})$ is the adsorption capacity at any time $t$. $F$ is the fraction of solute adsorbed at any time $t$ and $B_{t}$ is a mathematical function of $F$.

Solving the above two equations (15) and (16) we get

$$
B_{t}=-0.4977-\ln (1-F) \text {. }
$$

The $B_{t}$ values were plotted against time $t$, as shown in Figures 22 and 23 for adsorbent treated with $\mathrm{HCl}$ and $\mathrm{KOH}$, respectively. The linear lines for all concentrations did not pass through the origin showing that the adsorption of phenol on the chemically treated carbon was mainly governed by external mass transport where particle diffusion was the slowest step.

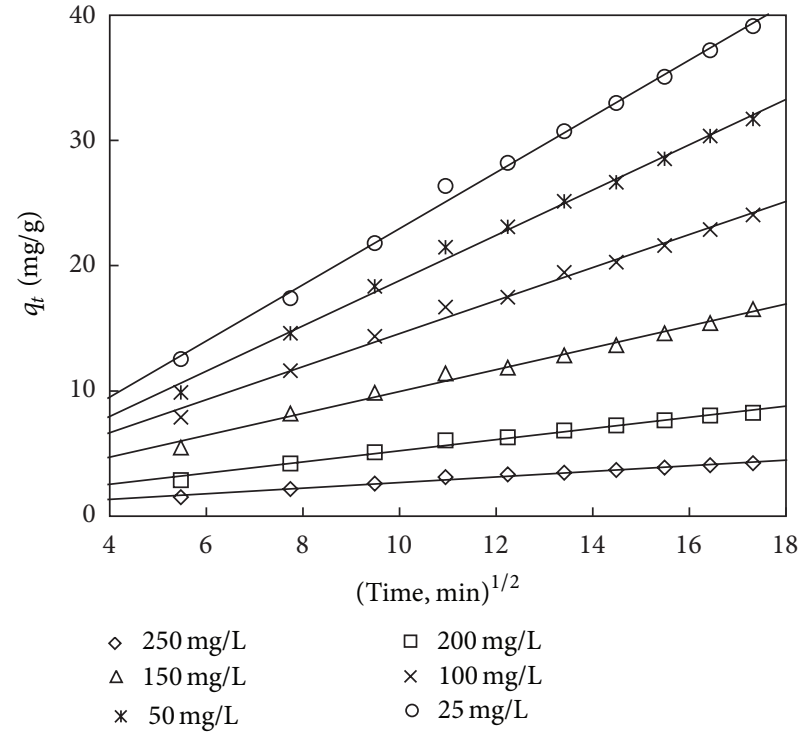

FIGURE 21: Intraparticle diffusion plot for adsorbent treated with $\mathrm{KOH}$.

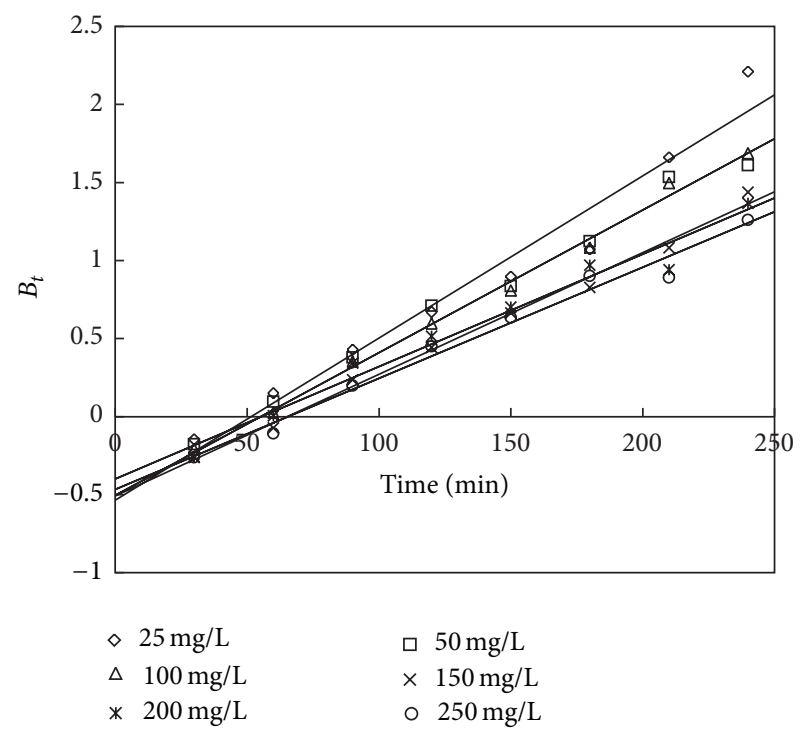

FIgURE 22: Boyd plot for adsorption of phenol onto adsorbent treated with $\mathrm{HCl}$

\section{Conclusions}

The current study shows that Lantana camara can be used as an effective adsorbent for the removal of phenol from aqueous solution. The proximate analysis and the estimation of various properties like specific surface area, pore volume, and average particle size signify the effectiveness of the adsorbent. The FTIR study revealed the types of chemical bonds responsible for adsorption. It was found that the amount of phenol adsorbed depended on the parameters like adsorbent dosage, initial dye concentration, $\mathrm{pH}$, and 


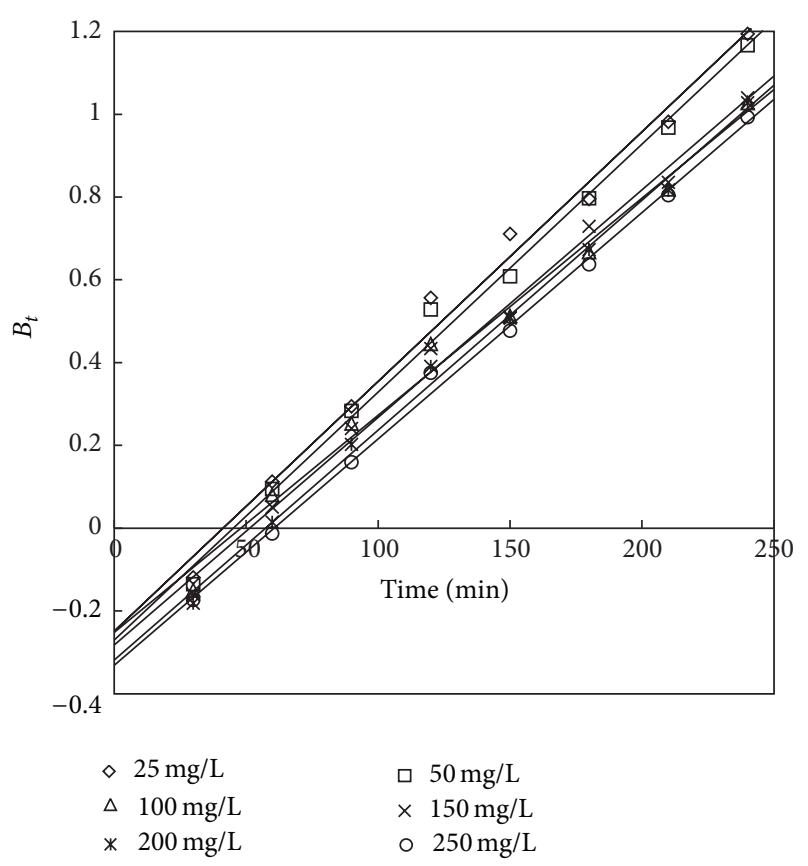

FIGURE 23: Boyd plot for adsorption of phenol onto adsorbent treated with $\mathrm{KOH}$.

temperature. The rate of adsorption followed pseudo-secondorder kinetics model with little deviation of the experimental values from the calculated values. The equilibrium data conform to the Langmuir isotherm equation with the monolayer adsorption capacity of $112.5 \mathrm{mg} / \mathrm{g}$ and $91.07 \mathrm{mg} / \mathrm{g}$ for adsorbent treated with $\mathrm{HCl}$ and $\mathrm{KOH}$, respectively. The determination of thermodynamic parameters shows that the adsorption process is feasible, spontaneous, and exothermic in nature. From the results obtained, the credibility of this forest waste as one of the most suitable precursors for the preparation of adsorbent for pollutant removal has enhanced manifold.

\section{Conflict of Interests}

The authors declare that there is no conflict of interests regarding the publication of this paper.

\section{References}

[1] H. Polat, M. Molva, and M. Polat, "Capacity and mechanism of phenol adsorption on lignite," International Journal of Mineral Processing, vol. 79, no. 4, pp. 264-273, 2006.

[2] H. Ucun, E. Yildiz, and A. Nuhoglu, "Phenol biodegradation in a batch jet loop bioreactor (JLB): kinetics study and $\mathrm{pH}$ variation," Bioresource Technology, vol. 101, no. 9, pp. 2965-2971, 2010.

[3] T.-P. Chung, H.-Y. Tseng, and R.-S. Juang, "Mass transfer effect and intermediate detection for phenol degradation in immobilized Pseudomonas putida systems," Process Biochemistry, vol. 38, no. 10, pp. 1497-1507, 2003.

[4] L. Damjanović, V. Rakić, V. Rac, D. Stošić, and A. Auroux, "The investigation of phenol removal from aqueous solutions by zeolites as solid adsorbents," Journal of Hazardous Materials, vol. 184, no. 1-3, pp. 477-484, 2010.

[5] F. Caturla, J. M. Martín-Martínez, M. Molina-Sabio, F. Rodriguez-Reinoso, and R. Torregrosa, "Adsorption of substituted phenols on activated carbon," Journal of Colloid And Interface Science, vol. 124, no. 2, pp. 528-534, 1988.

[6] C. R. Girish and V. Ramachandra Murty, "Review of various treatment methods for the abatement of phenolic compounds from wastewater," Journal of Environmental Science and Engineering, vol. 54, no. 2, pp. 306-316, 2012.

[7] G. M. Førland and A. M. Blokhus, "Adsorption of phenol and benzyl alcohol onto surfactant modified silica," Journal of Colloid and Interface Science, vol. 310, no. 2, pp. 431-435, 2007.

[8] F. An, B. Gao, and X. Feng, "Adsorption mechanism and property of novel composite material $\mathrm{PMAA} / \mathrm{SiO}_{2}$ towards phenol," Chemical Engineering Journal, vol. 153, no. 1-3, pp. 108113, 2009.

[9] T. G. Danis, T. A. Albanis, D. E. Petrakis, and P. J. Pomonis, "Removal of chlorinated phenols from aqueous solutions by adsorption on alumina pillared clays and mesoporous alumina aluminum phosphates," Water Research, vol. 32, no. 2, pp. 295302, 1998.

[10] A. Adak and A. Pal, "Removal kinetics and mechanism for phenol uptake by surfactant-modified Alumina," Desalination and Water Treatment, vol. 6, no. 1-3, pp. 269-275, 2009.

[11] R. I. Yousef and B. El-Eswed, "The effect of $\mathrm{pH}$ on the adsorption of phenol and chlorophenols onto natural zeolite," Colloids and Surfaces A: Physicochemical and Engineering Aspects, vol. 334, no. 1-3, pp. 92-99, 2009.

[12] S. Wang, H. M. Ang, and M. O. Tadé, "Novel applications of red mud as coagulant, adsorbent and catalyst for environmentally benign processes," Chemosphere, vol. 72, no. 11, pp. 1621-1635, 2008.

[13] A. Tor, Y. Cengeloglu, M. E. Aydin, and M. Ersoz, "Removal of phenol from aqueous phase by using neutralized red mud," Journal of Colloid and Interface Science, vol. 300, no. 2, pp. 498503, 2006.

[14] C. R. Girish and V. Ramachandra Murty, "Studies on adsorption of phenol from wastewater by agricultural waste," Journal of Environmental Science and Engineering, vol. 55, no. 3, pp. 275282, 2013.

[15] C. R. Girish and V. R. Murty, "Review on adsorption of phenol from wastewater using locally available adsorbents," Journal of Environmental Research and Development A, vol. 6, no. 3, pp. 763-772, 2012.

[16] A. T. Mohd Din, B. H. Hameed, and A. L. Ahmad, "Batch adsorption of phenol onto physiochemical-activated coconut shell," Journal of Hazardous Materials, vol. 161, no. 2-3, pp. 15221529, 2009.

[17] Y. A. Alhamed, "Adsorption kinetics and performance of packed bed adsorber for phenol removal using activated carbon from dates' stones," Journal of Hazardous Materials, vol. 170, no. 2-3, pp. 763-770, 2009.

[18] S. Kumar, K. Mohanty, and B. C. Meikap, "Removal of phenol from dilute aqueous solutions in a multistage bubble column adsorber using activated carbon prepared from Tamarindus indica wood," Journal of Environmental Protection Science, vol. 4, pp. 1-7, 2010.

[19] H. Cherifi, S. Hanini, and F. Bentahar, "Adsorption of phenol from wastewater using vegetal cords as a new adsorbent," Desalination, vol. 244, no. 1-3, pp. 177-187, 2009. 
[20] M. Achak, A. Hafidi, N. Ouazzani, S. Sayadi, and L. Mandi, "Low cost biosorbent "banana peel" for the removal of phenolic compounds from olive mill wastewater: kinetic and equilibrium studies," Journal of Hazardous Materials, vol. 166, no. 1, pp. 117$125,2009$.

[21] S. Rengaraj, S.-H. Moon, R. Sivabalan, B. Arabindoo, and V. Murugesan, "Agricultural solid waste for the removal of organics: adsorption of phenol from water and wastewater by palm seed coat activated carbon," Waste Management, vol. 22, no. 5, pp. 543-548, 2002.

[22] M. Z. Alam, E. S. Ameem, S. A. Muyibi, and N. A. Kabbashi, "The factors affecting the performance of activated carbon prepared from oil palm empty fruit bunches for adsorption of phenol," Chemical Engineering Journal, vol. 155, no. 1-2, pp. 191198, 2009.

[23] M. H. El-Naas, S. Al-Zuhair, and M. A. Alhaija, "Removal of phenol from petroleum refinery wastewater through adsorption on date-pit activated carbon," Chemical Engineering Journal, vol. 162, no. 3, pp. 997-1005, 2010.

[24] J. M. R. R. Arana and R. R. Mazzoco, "Adsorption studies of methylene blue and phenol onto black stone cherries prepared by chemical activation," Journal of Hazardous Materials, vol. 180, no. 1, pp. 656-661, 2010.

[25] S. Altenor, B. Carene, E. Emmanuel, J. Lambert, J.-J. Ehrhardt, and S. Gaspard, "Adsorption studies of methylene blue and phenol onto vetiver roots activated carbon prepared by chemical activation," Journal of Hazardous Materials, vol. 165, no. 1, pp. 1029-1039, 2009.

[26] H. D. S. S. Karunarathne and B. M. W. P. K. Amarasinghe, "Fixed bed adsorption column studies for the removal of aqueous phenol from activated carbon prepared from sugarcane baga SSE," Energy Procedia, vol. 34, pp. 83-90, 2013.

[27] O. Abdelwahab and N. K. Amin, "Adsorption of phen ol from aqueous solutions by Luffa cylindrica fibers: kinetics, isotherm and thermodynamic studies," The Egyptian Journal of Aquatic Research, vol. 39, no. 4, pp. 215-223, 2013.

[28] N. Priyanka and P. K. Joshi, "A review of Lantana camara studies in India," International Journal of Scientific and Research Publications, vol. 3, no. 10, pp. 1-11, 2013.

[29] A. P. Terzyk, "Further insights into the role of carbon surface functionalities in the mechanism of phenol adsorption," Journal of Colloid and Interface Science, vol. 268, no. 2, pp. 301-329, 2003.

[30] I. I. Salame and T. J. Bandosz, "Role of surface chemistry in adsorption of phenol on activated carbons," Journal of Colloid and Interface Science, vol. 264, no. 2, pp. 307-312, 2003.

[31] C. Moreno-Castilla, "Adsorption of organic molecules from aqueous solutions on carbon materials," Carbon, vol. 42, no. 1, pp. 83-94, 2004.

[32] S. Mishra and J. Bhattacharya, "Batch studies on phenol removal using leaf activated carbon," Malaysian Journal of Chemistry, vol. 9, no. 1, pp. 1-15, 2007.

[33] B. H. Hameed, R. R. Krishni, and S. A. Sata, "A novel agricultural waste adsorbent for the removal of cationic dye from aqueous solutions," Journal of Hazardous Materials, vol. 162, no. 1, pp. 305-311, 2009.

[34] APHA, Standard Methods for the Examination of Water and Wastewater, American Water Works Association, New York, NY, USA, 17th edition, 1989.

[35] H. B. Senturk, D. Ozdes, A. Gundogdu, C. Duran, and M. Soylak, "Removal of phenol from aqueous solutions by adsorption onto organomodified Tirebolu bentonite: Equilibrium, kinetic and thermodynamic study," Journal of Hazardous Materials, vol. 172, no. 1, pp. 353-362, 2009.

[36] I. A. W. Tan, A. L. Ahmad, and B. H. Hameed, "Preparation of activated carbon from coconut husk: Optimization study on removal of 2,4,6-trichlorophenol using response surface methodology," Journal of Hazardous Materials, vol. 153, no. 1-2, pp. 709-717, 2008.

[37] R. T. Morrison and R. N. Boyd, Organic Chemistry, Pearson Education, Singapore, 6th edition, 2004.

[38] B. H. Hameed, I. A. W. Tan, and A. L. Ahmad, "Adsorption isotherm, kinetic modeling and mechanism of 2,4,6trichlorophenol on coconut husk-based activated carbon," Chemical Engineering Journal, vol. 144, no. 2, pp. 235-244, 2008.

[39] C. Namasivayam and D. Kavitha, "IR, XRD and SEM studies on the mechanism of adsorption of dyes and phenols by coir pith carbon from aqueous phase," Microchemical Journal, vol. 82, no. 1, pp. 43-48, 2006.

[40] K. P. Singh, A. Malik, S. Sinha, and P. Ojha, "Liquid-phase adsorption of phenols using activated carbons derived from agricultural waste material," Journal of Hazardous Materials, vol. 150, no. 3, pp. 626-641, 2008.

[41] B. H. Hameed and A. A. Rahman, "Removal of phenol from aqueous solutions by adsorption onto activated carbon prepared from biomass material," Journal of Hazardous Materials, vol. 160, no. 2-3, pp. 576-581, 2008.

[42] I. A. W. Tan, A. L. Ahmad, and B. H. Hameed, "Adsorption isotherms, kinetics, thermodynamics and desorption studies of 2,4,6-trichlorophenol on oil palm empty fruit bunch-based activated carbon," Journal of Hazardous Materials, vol. 164, no. 2-3, pp. 473-482, 2009.

[43] V. C. Srivastava, M. M. Swamy, I. D. Mall, B. Prasad, and I. M. Mishra, "Adsorptive removal of phenol by bagasse fly ash and activated carbon: equilibrium, kinetics and thermodynamics," Colloids and Surfaces A: Physicochemical and Engineering Aspects, vol. 272, no. 1-2, pp. 89-104, 2006.

[44] V. Vadivelan and K. Vasanth Kumar, "Equilibrium, kinetics, mechanism, and process design for the sorption of methylene blue onto rice husk," Journal of Colloid and Interface Science, vol. 286, no. 1, pp. 90-100, 2005.

[45] P. Senthil Kumar, S. Ramalingam, C. Senthamarai, M. Niranjanaa, P. Vijayalakshmi, and S. Sivanesan, "Adsorption of dye from aqueous solution by cashew nut shell: studies on equilibrium isotherm, kinetics and thermodynamics of interactions," Desalination, vol. 261, no. 1-2, pp. 52-60, 2010.

[46] V. Srihari and A. Das, "The kinetic and thermodynamic studies of phenol-sorption onto three agro-based carbons," Desalination, vol. 225, no. 1-3, pp. 220-234, 2008.

[47] G. Akkaya and A. Özer, "Biosorption of Acid Red 274 (AR 274) on Dicranella varia: determination of equilibrium and kinetic model parameters," Process Biochemistry, vol. 40, no. 11, pp. 3559-3568, 2005.

[48] M. Sathishkumar, A. R. Binupriya, D. Kavitha, and S. E. Yun, "Kinetic and isothermal studies on liquid-phase adsorption of 2,4-dichlorophenol by palm pith carbon," Bioresource Technology, vol. 98, no. 4, pp. 866-873, 2007.

[49] B. H. Hameed, "Spent tea leaves: a new non-conventional and low-cost adsorbent for removal of basic dye from aqueous solutions," Journal of Hazardous Materials, vol. 161, no. 2-3, pp. 753-759, 2009.

[50] I. Langmuir, "The adsorption of gases on plane surfaces of glass, mica and platinum," The Journal of the American Chemical Society, vol. 40, no. 9, pp. 1361-1403, 1918. 
[51] H. M. F. Freundlich, "Over the adsorption in solution," Journal of Physical Chemistry, vol. 57, pp. 385-470, 1906.

[52] Y. S. Ho and G. McKay, "Sorption of dye from aqueous solution by peat," Chemical Engineering Journal, vol. 70, no. 2, pp. 115124, 1998.

[53] A. A. M. Daifullah and B. S. Girgis, "Removal of some substituted phenols by activated carbon obtained from agricultural waste," Water Research, vol. 32, no. 4, pp. 1169-1177, 1998.

[54] S. Veli and B. Alyüz, "Adsorption of copper and zinc from aqueous solutions by using natural clay," Journal of Hazardous Materials, vol. 149, no. 1, pp. 226-233, 2007.

[55] Y. Huang, X. Ma, G. Liang, and H. Yan, "Adsorption of phenol with modified rectorite from aqueous solution," Chemical Engineering Journal, vol. 141, no. 1, pp. 1-8, 2008.

[56] Q.-S. Liu, T. Zheng, P. Wang, J.-P. Jiang, and N. Li, "Adsorption isotherm, kinetic and mechanism studies of some substituted phenols on activated carbon fibers," Chemical Engineering Journal, vol. 157, no. 2, pp. 348-356, 2010.

[57] T. Budinova, E. Ekinci, F. Yardim et al., "Characterization and application of activated carbon produced by $\mathrm{H}_{3} \mathrm{PO}_{4}$ and water vapor activation," Fuel Processing Technology, vol. 87, no. 10, pp. 899-905, 2006.

[58] Y. S. Ho and G. McKay, "Pseudo-second order model for sorption processes," Process Biochemistry, vol. 34, no. 5, pp. 451465, 1999.

[59] W. J. Weber Jr. and J. C. Morris, "Kinetics of adsorption on carbon from solution," Journal of Sanitary Engineering Division, ASCE, vol. 89, pp. 31-59, 1963.

[60] W. H. Cheung, Y. S. Szeto, and G. McKay, "Intraparticle diffusion processes during acid dye adsorption onto chitosan," Bioresource Technology, vol. 98, no. 15, pp. 2897-2904, 2007. 

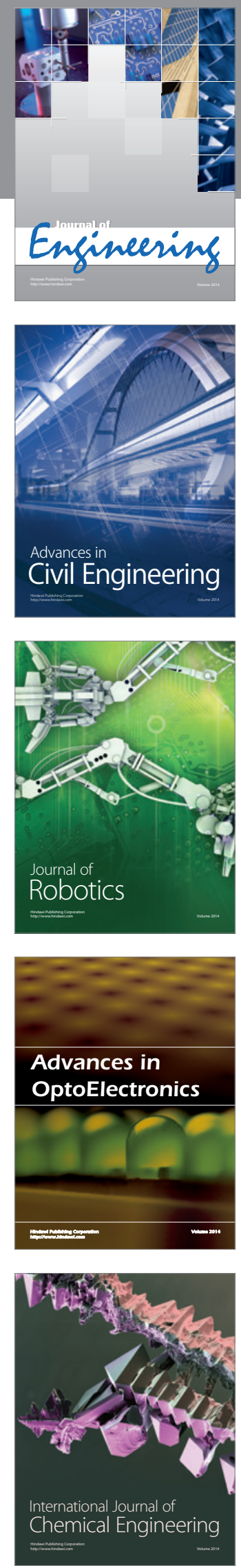

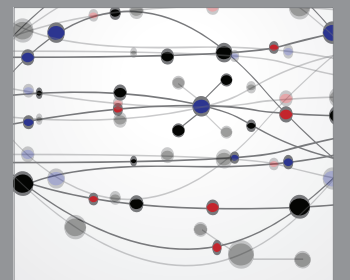

The Scientific World Journal
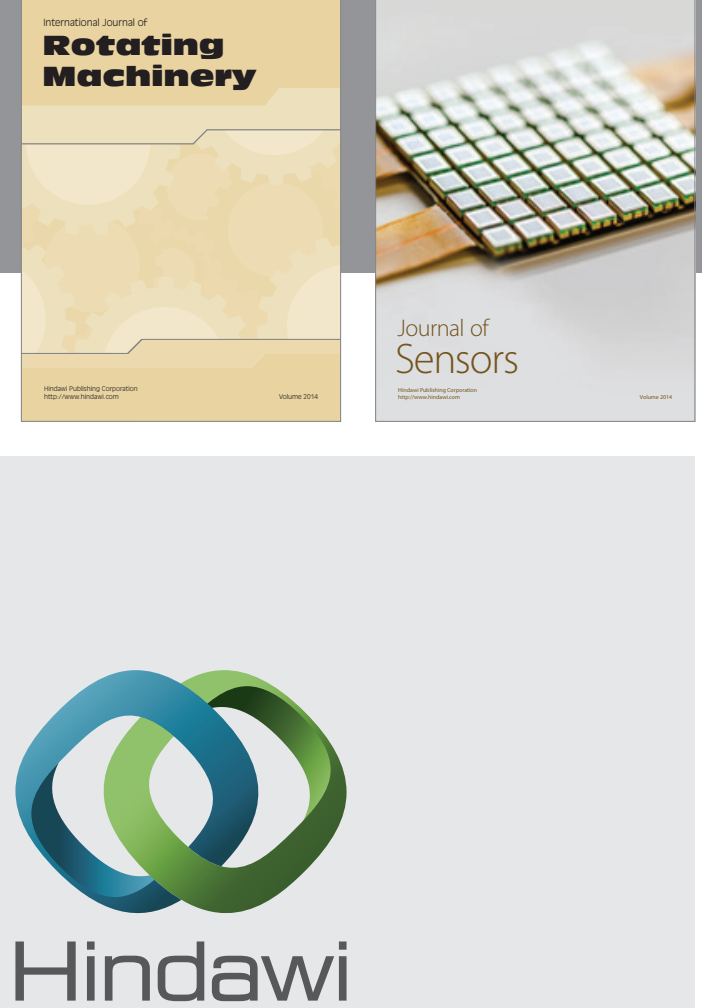

Submit your manuscripts at http://www.hindawi.com
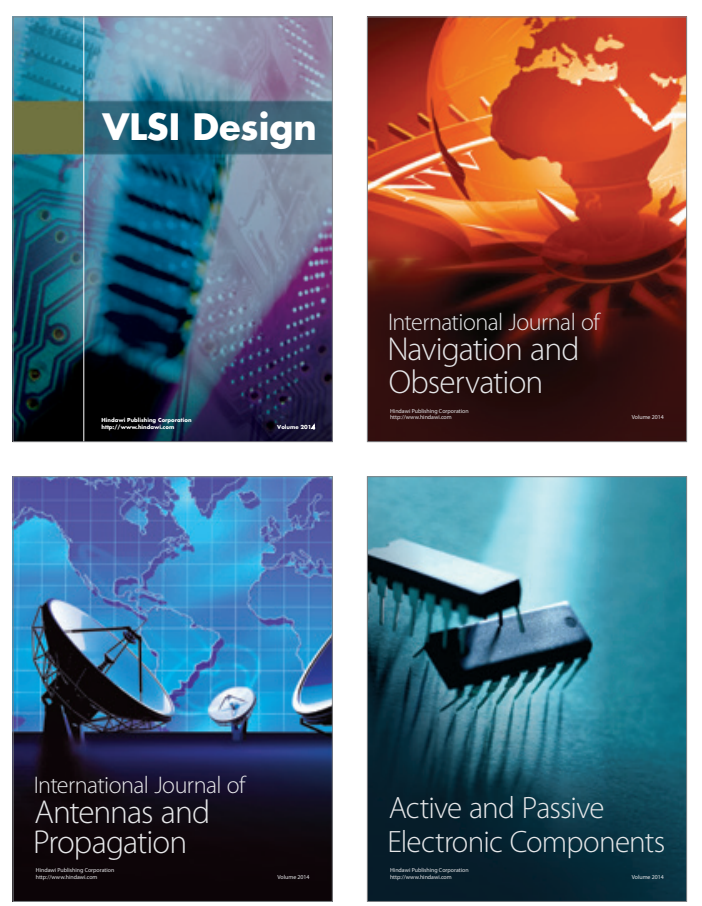
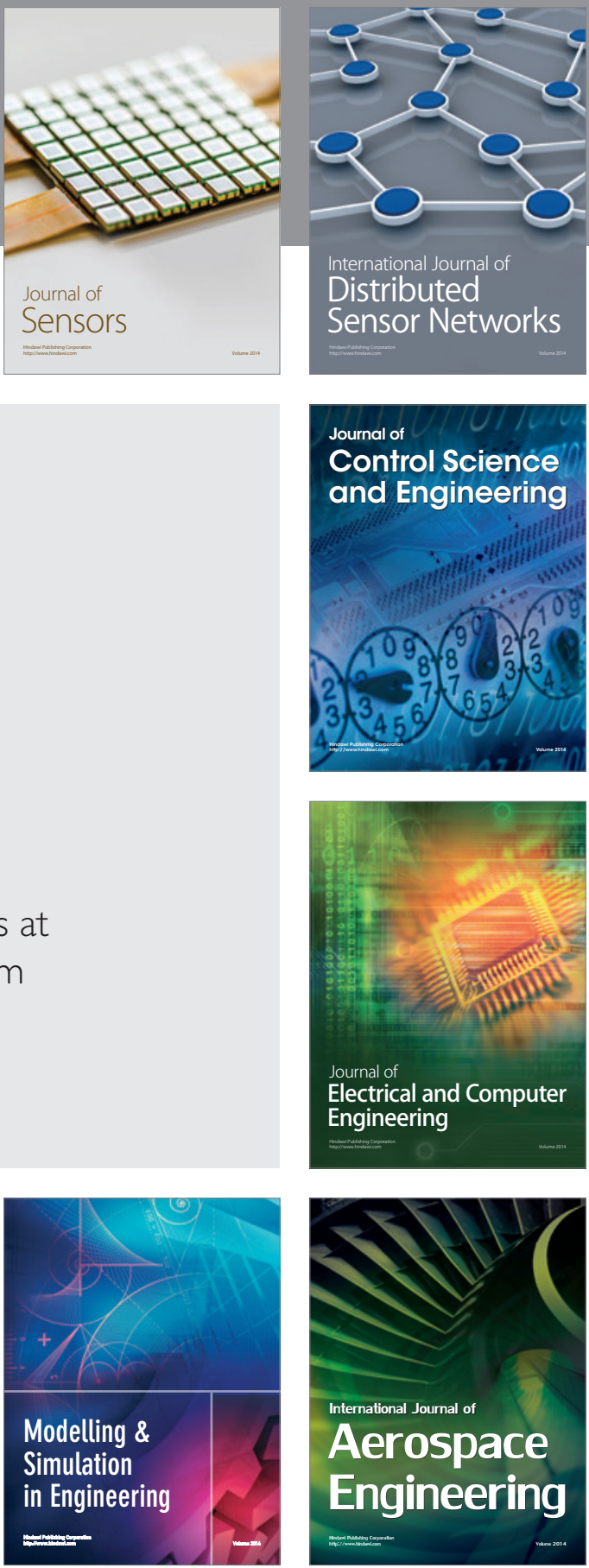

Journal of

Control Science

and Engineering
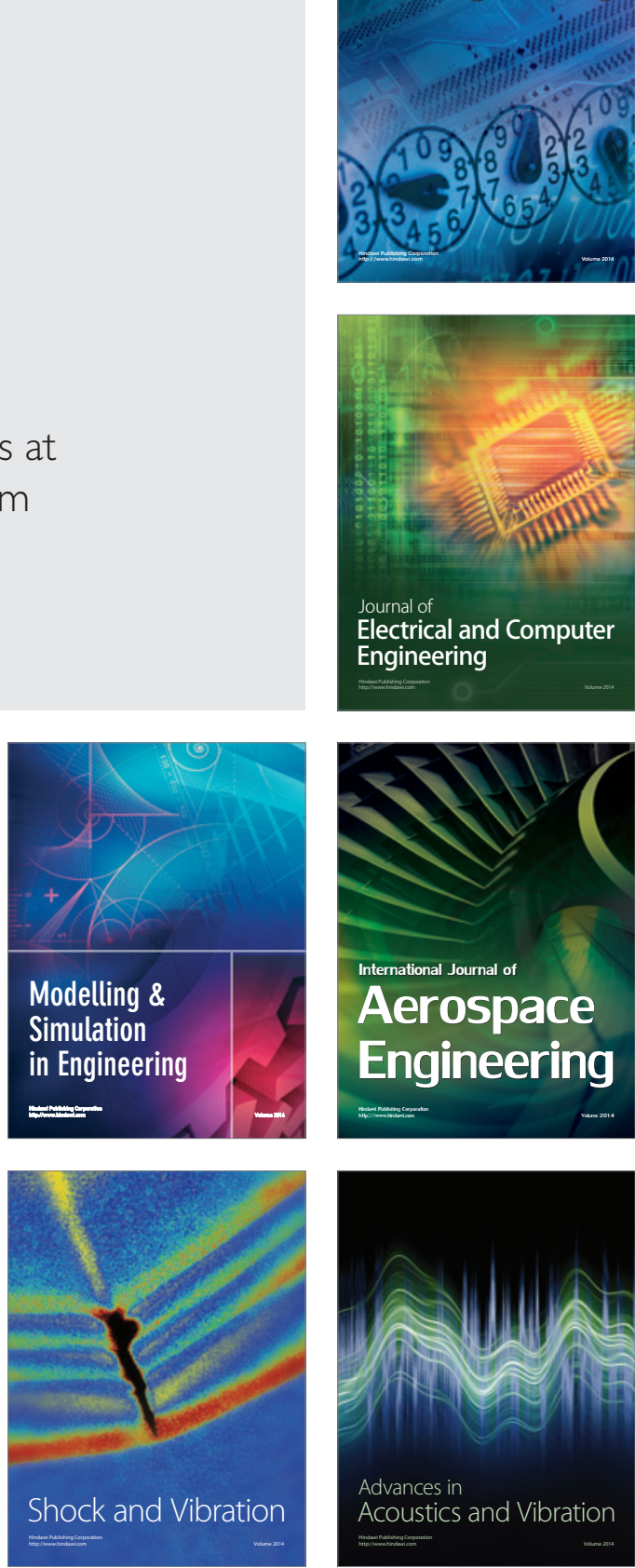